\title{
CROSS-BORDER JURISDICTION AND ASSISTANCE IN INSOLVENCY: THE POSITION IN MALAYSIA AND SINGAPORE
}

\section{PJ Omar*}

\section{$1 \quad$ Introduction $^{1}$}

Comity amongst nations has been an ideal, if difficult to achieve, particularly so in insolvency matters. That said, the judges in the common law have had to face the issues raised in the context of cross-border insolvencies, especially those of traders, from an early time. There is a considerable literature devoted to the phenomenon of international insolvency, initiated largely by the consequences of globalisation and the (inevitable) economic meltdown caused by the convergence of markets and economic cycles. An idea of the scale of this phenomenon, and its ensuing importance, can be gauged from the identity of those businesses established at the global level that have experienced insolvencies, including Barings, Bank of Credit and Commerce International, Maxwell Communications, Olympia and York, Enron, World.Com and Parmalat, some of which have had a presence in Malaysia and Singapore, the two countries that are the subject of this article. The reason for the focus on these countries, which, although now separate nations within the Commonwealth, are two jurisdictions with a shared legal and political history, is two-fold. Firstly, they are countries that are midway on the stage between developing and developed, their economies being advanced in comparison with some of their neighbours. Secondly, as members of the common law family, they exhibit a history of involvement in the phenomenon of international insolvency and measures assisting co-operation in insolvency that may serve as an example to those considering developments in this field. Furthermore, as members of the

* Dr Paul Omar. Barrister, Gray's Inn; Advocate and Solicitor, High Court of Malaya; Senior Lecturer, University of Sussex.

1 The genesis of this paper comes from research initially explored in two articles first published as "Co-operation in International Insolvencies" in Omar 1996 MalLJ i and Omar 1998 MalLJ cxxi. 
Association of South East Asian Nations (ASEAN), both Malaysia and Singapore are integrated in a regional framework that is growing in importance in trade terms globally, a fact that may itself militate for closer attention to be paid in the jurisdictions themselves to the phenomenon of cross-border insolvency. By way of note, this article deals predominantly with cross-border insolvency in the corporate context, although references to bankruptcy (personal insolvency) will be made where appropriate.

\section{Preliminary issues}

In order to understand the references below to the law of Commonwealth nations apart from Malaysia and Singapore, it is necessary to first understand the place of these two countries within the common law family and to appreciate how their domestic insolvency laws, both substantive and procedural, have been affected by developments within that family.

\subsection{The place of Malaysia and Singapore within common law nations}

The history of both Malaysia and Singapore is tied to the expansion of the British East India Company, which established a presence on the island of Penang (then named the Prince of Wales Island) in 1786. Settlements in Malacca and Singapore followed in 1824 and 1826 respectively, the three territories being united as the Straits Settlements Colony in 1826, although administered from Calcutta. In 1867, the colony became a Crown Colony, administered locally, but answerable to the Colonial Office from London. Certain princely states on the Malayan Peninsula, which had entered into a relationship with the United Kingdom, were united as the Federated Malay States in $1895,{ }^{2}$ while control over the four northern states (the Unfederated Malay States) ${ }^{3}$ passed from Thailand under the Anglo-Siam Treaty 1909. The Malayan Union was formed from these three blocs in 1946 (with the exclusion 
of Singapore) with the Federation of Malaya obtaining independence in 1957. Malaysia was formed in 1963 with the addition of other Crown Colonies, including Singapore, North Borneo (later renamed Sabah) and Sarawak. After political differences, Singapore seceded from the federation in 1965. Both countries are sovereign members of the United Nations as well as the Commonwealth. Although both their systems of government are rooted in parliamentary democracy, there are some differences in the identity of the Head of State, Malaysia's being chosen by the Conference of Malay Rulers from its members to serve five years, ${ }^{4}$ while Singapore's is a President elected to serve a term of six years. ${ }^{5}$

In terms of law, the legal history of the jurisdictions is as complex as their political antecedents. Charters of Justice dated 1807 and 1826 introduced English law into Penang, Malacca and Singapore, although magistrates in the Straits Settlements were given considerable latitude in adapting it to local needs. ${ }^{6}$ The Civil Law Ordinance 1878 effected the formal introduction of English commercial law into Penang, Malacca, Sabah and Sarawak. ${ }^{7}$ The Malay States (Federated and Unfederated) applied indigenous law and custom, although a number of laws were introduced into the Federated Malay States, which were patterned on developments in British India, including the Criminal Procedure Code 1902 and the Penal Code 1905. ${ }^{8}$ The Civil Law Enactment 1937 and the Civil Law (Extension) Ordinance 1951 effected the introduction of English common law and equity into the Malay States. ${ }^{9}$ In Sarawak and Sabah, statutory reception of English law was effected by the Law of Sarawak Ordinance 1928 (revised 1949) and Civil Law Ordinance 1938 (revised 1951) respectively. ${ }^{10}$ All of these enactments were subsumed into the Civil Law Act $1956,{ }^{11}$ which provides in section 3 for various terminal dates for reception of

\section{Art 32, Malaysian Constitution.}

Art 17 and 20, Singapore Constitution.

See Wu Malaysian Legal System 14-16.

Ibid at 17.

Ibid at 23-24.

Ibid at 25.

10 Ibid at 29-30.

11 Act 67 of the Federal Statute Series. 
English common law and equity. ${ }^{12}$ Section 6(1) of the same act provides that English commercial law will apply to the states in West Malaysia as of the commencement date of the act on 7 April 1956. Curiously, section 6(2) of the act goes on to provide for continuing reception of commercial law, except where ousted by local law, in Penang, Malacca, Sabah and Sarawak, leading to the possibility that developments in the law of the United Kingdom may be applicable directly as part of the law in these states. ${ }^{13}$ In Singapore, the Charter of Justice 1826 effected the introduction of English common law and equitable principles on 27 November 1826 subject to the existence of local laws and insofar as their application was not repugnant to local custom or conditions. ${ }^{14}$ Apart from this general reception, section 5 of the Civil Law Act 1956 provided for continuing reception of English commercial law. ${ }^{15}$ Nonetheless, postindependence, in light of some uncertainty as to what English law was thus being imported, the Application of English Law Act 1993 restated the adoption date for common law and equity as at 12 November 1993 with a limited number of statutes being expressly extended in the First Schedule, all others being declared not to form part of the law of Singapore. ${ }^{16}$ That said, in relation to all the jurisdictions noted, English case law continues to have the status of persuasive precedent and the adoption locally of principles and rules developed elsewhere in the common law family of nations continues to occur.

\subsection{Insolvency procedures in Malaysia and Singapore}

Unsurprisingly, given that company and insolvency law is commercial law par excellence, statutory developments in the United Kingdom and elsewhere in the common law world have influenced statutory developments in Malaysia and

12 Wu supra n 6 at 99-102. The dates aRe 12 December 1949 (Sarawak), 1 December 1951 (Sabah) and 7 April 1956 (all states in West Malaysia). For Sarawak and Sabah, statutes of general application are also deemed to be received, while certain UK enactments expressly mentioned in the Second Schedule apply to Sarawak.

13 Ibid at 106-111.

14 Yeap Cheah Neo v Ong Cheng Neo (1875) LR 6 PC 381.

15 Cap 43 of the Statutes of Singapore (1988 rev ed), this section now repealed. See Chang http://www.aseanlawassociation.org/ 31 Aug at 6.

16 Cap 7A of the Statutes of Singapore (1993 rev ed). See Chang supra n 15 at 7-8. 
Singapore. ${ }^{17}$ In fact, one of the by-products of the Victorian codification experiment in commercial law was the extension of legislation to the Imperial possessions, whether expressly or as "statutes of general application". ${ }^{18}$ Thus, the first company law statute to be applied in the Straits Settlements was the Indian Companies Ordinance 1866, which was replaced by a local ordinance in 1889, itself replaced by successor legislation in 1915, 1923 and 1940. The Federated Malay States applied a Companies Enactment 1897, replaced in 1917. Similar laws were made applicable in each of the Unfederated Malay States as local enactments. The various drafts of these ordinances and enactments generally reflected the model of English company law statutes prevailing at the time. The formation of the Malayan Union saw the extension of the Straits Settlements regime to the Malay States, which was maintained after Malayan independence in 1957 and the formation of Malaysia in 1963. Although West Malaysia and Singapore thus had the same law, the addition of two new statutes in the shape of the Sabah and Sarawak equivalents, the Companies Ordinances 1950 and 1956 respectively, prompted the Government to form a committee to consider the introduction of a single unified act. The influences behind what became the Companies Act $1965^{19}$ were the United Kingdom Companies Act 1948, the Australian Uniform Companies Act 1961 and the Ghanaian Companies Code drafted by Professor Gower in $1963 .^{20}$ Although Singapore had left the Federation by the time the act came into force, the Singapore Companies Act 1967 was identical in most respects to the Malaysian legislation. ${ }^{21}$

Given the similarity between the Acts and their relationship to statutory developments in other common law jurisdictions, it is not surprising, therefore, with regard to corporate insolvency, the relevant Companies Acts outline two basic types of insolvency measures that will be familiar to readers in the common law world. In the first case, creditors are able to appoint a receiver and

17 See CCM http://www.ssm.com.my/clrc/cd1.pdf 31 Aug at 12.

18 See Roberts-Wray Commonwealth and Colonial Law 554-555.

19 Act 125 of the Federal Statute Series (hereafter CAM).

20 CCM supra $\mathrm{n} 17$ at 13.

21 Cap 50 of the Statutes of Singapore (2006 rev ed) (hereafter CAS); Woon Company Law at 4 . 
manager in respect of the debtor company. ${ }^{22}$ Furthermore, an application may be made to court for the commencement of winding-up proceedings, which may be further subdivided into three types: members' voluntary winding-up, creditors' voluntary winding-up and winding-up by the court. ${ }^{23}$ Apart from the two insolvency-related measures, general company law offers to a company the possibility of entering into a scheme of arrangement for the reconstruction of its finances. ${ }^{24}$ In Singapore, the list of available procedures has been supplemented by the addition of judicial management, based on its British counterpart of administration. ${ }^{25}$ Judicial management is a procedure principally applicable to locally incorporated companies in a situation of imminent or technical insolvency and whose primary purpose is to avoid the inevitable consequences of winding-up, which are the liquidation of assets, destruction of viability and consequent loss of employment. In Malaysia, the passing of the Pengurusan Danaharta Nasional Berhad Act 587 of 1998 has resulted in a further procedure allowing for the special administration of financially distressed companies through the management of non-performing loans, in effect a form of state-sponsored insolvency proceedings. ${ }^{26}$ Finally, also of a similar genesis to the corporate provisions, the bankruptcy model springs directly from the United Kingdom Bankruptcy Act 1883 and its successor consolidation statute, the Bankruptcy Act 1914, which were exported to a number of Commonwealth countries, ${ }^{27}$ including the Straits Settlements in $1888 .{ }^{28}$ The Bankruptcy Ordinance of the States of Malaya, the Bankruptcy Ordinance of Sarawak ${ }^{29}$ and the Insolvency Ordinance of Sabah, ${ }^{30}$ all substantially similar in scope to

22 Part VIII, CAM and CAS.

23 Part $X, C A M$ and CAS.

24 Part VII, CAM and CAS.

25 Part VIIIA, CAS (which resembles the administration regime prior to the amendments introduced by the Enterprise Act 2002 (UK)).

26 For the workings of this act, see Bidin 2004 ICCLR 344. It is noteworthy that the Malaysian Government has now suspended the operations of the Danaharta Company. See Danaharta Final Report http://www.danaharta.com.my 31 Aug.

27 See Markham Victorian Insolvency 295-296 for a list of colonies and territories to which the acts were extended.

28 Incorporated in 1965 as Cap 20 of the Statutes of Singapore (2000 rev ed) (hereafter BAS), although considerably amended by the Bankruptcy Act 15 of 1995.

29 Sarawak Cap 46.

30 Sabah Cap 62. 
the Straits Settlements legislation, were all merged in the Malaysian Act in $1967 .^{31}$

\section{The common law position}

\subsection{Recognition of judgments}

It is a general principle of law that the law of the state of incorporation of the company governs its status from creation to dissolution. ${ }^{32}$ This is irrespective of the fact that the company may well operate principally or exclusively in another jurisdiction. The general principle stated here is recognised by the courts of Malaysia and Singapore. ${ }^{33}$ The extension of this principle would also require recognition of a foreign liquidation order that has been granted in the home jurisdiction, or domicile, of the company. This also includes recognition of the authority of a liquidator appointed by virtue of any order. ${ }^{34}$ In addition, orders pronounced by other jurisdictions may also be recognised provided the basis of jurisdiction approximates to grounds normally accepted by the local court. This is subject to certain common law exceptions to recognition based on whether foreign proceedings are final in nature, whether they comply with perceived notions of natural justice, whether jurisdiction has been exercised validly and whether recognition would offend public order rules. ${ }^{35}$ One of the more problematic areas has been the position of foreign revenue claims in insolvency owing to judicial views that to allow collection of such claims would offend public policy. ${ }^{36}$ This view has had to be relaxed in the United Kingdom for

31 Act 55, revised in 1988 and republished as Act 360 of the Federal Statute Series (hereafter BAM). This Act was also the subject of amendments in the Bankruptcy (Amendment) Act 2003 (Act A1197).

32 See North and Fawcett Private International Law at 897 (the chapter containing this quote was omitted from the later 1999 edition).

33 Lazard v Midland Bank [1933] AC 283, cited as authority in Woon and Hicks Companies Act of Singapore at par 2:1301. It is submitted this principle is also valid for Malaysia.

34 There is Australian authority to this effect: Re Alfred Shaw and Co (1897) QLJ 93. This accords with the principle outlined in Rule 178 in Collins et al (eds) Conflict of Laws 1150 and, it is submitted, is also valid in Malaysia and Singapore.

35 See Wood Principles of International Insolvency 250 at par 5-13.

36 Government of India v Taylor [1955] AC 491. See Miller JG "Bankruptcy and Foreign Revenue Claims" (1991) JBL 144. For an interesting view contra, see Dawson K "An Extraterritorial Dichotomy?" [2000] 2 Insolv L 81, 83-85. 
proceedings taking place under the European Insolvency Regulation, ${ }^{37}$ which does not distinguish between claims made by private or public bodies, and there is some support for a change in this position elsewhere in the Commonwealth. ${ }^{38}$

The traditional common law doctrine is that a foreign order, although creating an obligation that is actionable within the jurisdiction, cannot be enforced without the institution of fresh legal proceedings. ${ }^{39}$ This is said to be on grounds that courts recognise the limitation of their own power, if making an order in similar circumstances, to affect assets of a company abroad without the express consent of the foreign court to initiate and assist proceedings. In this connection, it has been stated that the proposed winding-up in Singapore of a company incorporated in Malaysia would normally only affect assets within the jurisdiction of the court making the order and could not by its nature have full force and effect throughout Malaysia. ${ }^{40}$ Recognition is thus not tantamount to enforcement of the foreign order within the jurisdiction. Nevertheless, it is stated by commentators that, although a foreign liquidation order is not directly enforceable, it is assisted by the recognition of the appointment of the foreign liquidator and allowing him capacity to act in certain instances. ${ }^{41}$ Nevertheless, the exercise of this capacity to act may be limited as it has been held that powers available to a liquidator, including those to require examination of a company's directors, are not available to a foreign liquidator, where no proceedings were opened in Singapore in respect of the foreign company. ${ }^{42}$

\subsection{Exercise of domestic jurisdiction}

The recognition of the subjection of a foreign company to a foreign law does not necessarily mean the domestic courts will not assume some jurisdiction over

37 Council Regulation (EC) No 1346/2000 29 May 2000.

38 Radich v Bank of New Zealand (1993) 116 ALR 676.

39 North and Fawcett supra n 32 at $407\left(13^{\text {th }}\right.$ ed).

40 Tong Aik (Far East) v Eastern Minerals Trading (1959) [1965] 2 MLJ 149.

41 See Cooper and Jarvis (eds) Cross-Border Insolvency 7 (Australia) and 103 (Singapore).

42 Re China Underwriters Life and General Insurance [1988] 1 MLJ 409. 
the issues in contention. ${ }^{43}$ What is clear is that the courts have had to take account of the existence of companies operating within the jurisdiction that have subsequently become insolvent. The nature of these proceedings is described as ancillary to main proceedings being undertaken in the home jurisdiction of the company. The case law developed in response to the growing problem of insolvencies of institutions with operations in the United Kingdom and the Dominions. In Re Matheson, ${ }^{44}$ which concerned a winding-up petition presented by a creditor against a company already in liquidation in New Zealand, the proposition was stated that a foreign order -

does not take away the rights of a court of this country to make a winding-up order here, though it would no doubt exercise an influence upon this court... ${ }^{45}$

The affirmation of this jurisdiction was prompted by the need to secure assets in England to protect the rights of creditors and third parties present within the jurisdiction. In Re Commercial Bank of South Australia, ${ }^{46}$ on the suspension of a bank incorporated in South Australia followed by a winding-up order, the creditors were held entitled to a winding-up order in England, the nature of which was described by the judge as being as ancillary to the winding-up in Australia. ${ }^{47}$ The extension of this jurisdiction involves determining the precise application of provisions of company legislation to foreign companies. In $R e$ Mercantile Bank of Australia ${ }^{48}$ the power to appoint a receiver ${ }^{49}$ and to require

43 See s 4(1), CAM which reads: "In this Act, ... 'foreign company' means - (a) a company, corporation, society, association or other body incorporated outside Malaysia; or (b) an unincorporated society, association or other body which under the law of its place of origin may sue or be sued or hold property in the name of the secretary or other officer of the body or association duly appointed for that purpose and which does not have its head office or principal place of business in Malaysia;....". The definition provided in s 4, CAS is similar. The definition of an 'oversea company' in s 744, Companies Act 1985 (UK) requires that a company incorporated elsewhere has a place of business within the UK for the purposes of Part XXIII of that act, while s 1044 and 1046, Companies Act 2006 (UK) now require that registration take place if the company establishes a presence in the UK.

44 Re Matheson Brothers (1884) 27 Ch D 225.

45 At 230 (per Mr Justice Kay).

46 Re Commercial Bank of South Australia (1886) 33 Ch D 174.

47 At 178 (The judge continues to state that care would be taken to ensure there would be no conflict between the courts and that costs would be kept down while the interests of all creditors would be looked after).

48 Re Mercantile Bank of Australia [1892] 2 Ch 204.

49 S 4, Companies (Winding-Up) Act 1890 (UK). See also s 135, Insolvency Act 1986 (UK), s 231, CAM. 
security to be given by a liquidator ${ }^{50}$ was held applicable to a company incorporated in Victoria but conducting business in London, where an ancillary order was stated as desirable though postponed till the outcome of shareholder negotiations in Australia was known. The relationship of various classes of creditors standing to gain or lose by the winding-up process may influence the decision of a court as is seen in the case of Re English, Scottish and Australian Chartered Bank, ${ }^{51}$ in which a company incorporated in England, whose principal business was in Australia, was due to be wound up in England. A scheme of reconstruction was proposed needing the assent of a meeting of the creditors and shareholders. Proxies were obtained from Australian creditors for a meeting in London, at which the resolutions were carried, subsequently sanctioned by order of court. British creditors appealed stating that, but for the Australian proxies, the scheme would not have met with the approval of British creditors. It was held that as there was nothing unreasonable or unfair in the scheme as between different classes of creditors, the expressed majority opinion should prevail. The general principle was stated that the courts of the country of domicile should act as the principal court, while "other courts act as ancillary... to the principal liquidation". ${ }^{52}$

Courts are normally keen to ensure that the priorities between proceedings in different jurisdictions are firmly set to ensure that any disparity in rights available to creditors acting in different jurisdictions do not affect the overall settlement of the liquidation. Thus, a court may grant the enforcement of rights acquired in priority to insolvency proceedings beginning, ${ }^{53}$ though any disparity in the treatment of creditors may prompt the court to restrain one class of creditor from exercising rights available in another jurisdiction, as in the case of Re Vocalion, ${ }^{54}$ where a company registered in England was also registered in Victoria as a foreign company. The Bank of New South Wales claimed a sum

50 Rule 67, Companies (Winding-Up) Rules 1890 (UK). See rule 4.28, Insolvency Rules 1986 (UK) and rule 47, Companies (Winding-Up) Rules 1972 (Malaysia).

51 Re English, Scottish and Australian Chartered Bank [1893] 3 Ch 385.

52 At 394 (per Mr Justice Vaughan Williams).

53 Galbraith v Grimshaw [1910] AC 508, in which a garnishee order obtained by judgment creditor was held to have priority over the sequestration of the judgment debtor's assets.

54 Re Vocalion (Foreign) Ltd [1932] 2 Ch 196. 
owing for commission on banking work as well as for sums lent to the company and, in a separate action, for specific performance by the company and its registered agent in Victoria, of an undertaking by the agent to give security for the company to the bank, both of which actions were before the courts of Victoria. On the liquidation of the company in England, the Official Receiver sought an order restraining the bank from proceeding with its action in Victoria. It was held in that case that a court may in the exercise of its equitable jurisdiction restrain a party from proceeding with an action on liability incurred abroad brought in a foreign court. Where a company is domiciled abroad by registration as a foreign company, substantial justice is more likely to be attained by allowing the foreign proceedings to continue. In fact, as the trial judge stated:

...foreign creditors ... can not be restrained from taking such proceedings ... in their own country; ... the only result of such an injunction ... may be to benefit other foreign creditors without in any way increasing the amount of the assets ... distributable in the liquidation in this country. ${ }^{55}$

The costs of an ancillary liquidation may well amount to the equivalent of a full liquidation, particularly if decisions of liquidators are contested in several jurisdictions. The increase in costs is a factor that often motivates courts in deciding whether to permit further litigation as, from a practical standpoint, the result can only be to the detriment of creditors. The discretion to permit proceedings is also influenced by the just merits of the creditors' claims and the unfair result on their position especially where the company concerned, as in the case of $R e$ Suidair, ${ }^{56}$ had acted to the detriment of creditors in one jurisdiction. The case involved a company incorporated in South Africa with an office in London, which defaulted on payments for goods sold by an English creditor, whereupon the latter commenced proceedings and obtained judgment in default. At the same time, a winding-up petition was presented by a creditor in South Africa and a provisional liquidator appointed. On discovering this, the English creditor issued writs of fieri facias on goods of the company. The South 
African liquidation being final, the liquidator claimed the goods, at which point another creditor in England also presented a winding-up petition. The first English creditor sought the benefit of their judgment against the liquidator in England. It was held that it was entitled to benefit from the judgment obtained, which but for the conduct of the company, in allowing other creditors to come in, would already have been met. The rule stated in Re English, Scottish and Australian Chartered Bank ${ }^{57}$ did not mean that an ancillary winding-up would be decided by rules of the main procedure, under which the South African liquidator would have been entitled to the assets in England at the expense of the creditor, nor did it mean that the ancillary jurisdiction would be bound to give effect to decisions of the other court on points of law or procedure.

The ability of foreign liquidators to operate in the ancillary jurisdiction is of considerable advantage but not without some degree of difficulty. ${ }^{58}$ Apart from the question of recognition of the liquidator's qualification to act, there is the question of the degree of responsibility the liquidator may owe to the court in the main jurisdiction, which may lead to conflict between courts exercising jurisdiction in the same insolvency. This subject was treated in the case of Schemmer, ${ }^{59}$ where in the course of an investigation by the United States Securities Exchange Commission into the affairs of a company incorporated in the Bahamas, an action was brought in the Federal District Court in the Southern District of New York which resulted in the appointment of a receiver over assets, including the shares and assets of another company (also a Bahamian company) and its subsidiaries, controlled for the most part by the first company. The receiver sought to be appointed receiver of the company and its subsidiaries in the United Kingdom and requested injunctions against

57 Re English, Scottish and Australian Chartered Bank [1893] 3 Ch 385.

58 See s 340(2)(b), CAM which reads: s 340(2) "If a foreign company goes into liquidation or is dissolved in its place of incorporation or origin-...(b) the liquidator shall, until a liquidator for Malaysia is duly appointed by the court, have the powers and functions of a liquidator for Malaysia." Though this section does not expressly prohibit the appointment of a foreign liquidator to act in Malaysia, s 340(3)(c) on the satisfaction of Malaysian debts in priority before any excess is transferred for the benefit of foreign proceedings makes it highly unlikely a court would sanction such an appointment in what is clearly a situation of conflict of interest. See also s 377(2)(b) and s 377(3)(c), CAS.

59 Schemmer and Others v Property Resources Ltd and Others [1975] 1 Ch 273. 
three banks holding money for the company. The company then applied for the discharge of the order granting leave to serve the writ.

It was held that before the English courts would recognise the title of a foreign receiver to assets in the jurisdiction or direct the establishment of ancillary receivership proceedings, the courts would have to be satisfied of the nexus between the defendant companies and the jurisdiction in which the receiver was appointed. Had the receiver been appointed in the Bahamas, there might have been a sufficient connection. A particular result of the development of case law in this field is that the courts have not been slow to entertain the institution of ancillary proceedings where these are appropriate. The question of whether the ancillary jurisdiction may take a lead in the proceedings is one that has often been put, especially where the connection of the foreign company is greater with the ancillary jurisdiction. A recent example in the United Kingdom is the case of Re A Company (1987), ${ }^{60}$ in which a company registered in Liberia, operated mainly through London shipping agents. It defaulted on payments due under an agreement for the construction of a vessel subject to a mortgage given to International Westminster Bank. The bank declared the whole indebtedness to be due under the loan agreement and obtained judgment for the amount. The bank subsequently presented a petition for the winding-up of the company. For a court to make a winding-up order against a foreign corporation, it was held not necessary to show that the company had assets within the jurisdiction but that there was a close link with the jurisdiction, which on the facts: company management, bank accounts and main business situated within the jurisdiction, made the courts in England the most appropriate to deal with the matter. As there was conceivably an advantage to the creditors in having a winding-up in England, an order would be made.

The precise role to be played by the ancillary jurisdiction in cases where proceedings were at an advance stage in the main jurisdiction is often a point of contention between the courts. It may be that the ancillary jurisdiction would prefer a winding-up to be instituted while the main jurisdiction has in mind 
preservation proceedings, enabling the company to continue its operations in a restricted form, with appropriate court supervision. These issues were the subject of the leading case of Felixstowe, ${ }^{61}$ where United States Lines, a company incorporated in the United States, was registered as an oversea company in England. It entered a moratorium on payments under American bankruptcy law. ${ }^{62}$ Felixstowe and other plaintiffs instituted actions on debts owed in England by the American company and obtained Mareva injunctions, ${ }^{63}$ the effect of which was to require the company to retain sufficient assets within the jurisdiction to meet any judgments against them. The American company, which wanted to hive down its operations in Europe applied to have the injunctions set aside, arguing that an English court should recognise the procedures being followed in the United States, under which a restraining order had been granted against any suit outside the United States. The maintenance of the injunction would serve to prevent administration according to United States procedures by a United States court and would have the effect of granting the plaintiffs priority over other creditors. The proper approach of an English court was to regard the courts of the country of incorporation as the appropriate legal forum for controlling the winding-up of that company. Where that company had assets in England, the normal procedure was to carry out an ancillary winding-up in harmony with the main court. However, a United States restraining order that required assets to be moved outside the jurisdiction could have no effect in England on an English court. It was noted that, as the English practice was in harmony with certain provisions of the United States Bankruptcy Code, ${ }^{64}$ and, on the balance of convenience test, the American company suffered no material prejudice as the assets remained preserved with no garnishee orders being permitted, the injunctions would be continued. The judge noted:

61 Felixstowe Dock and Railway v United States Lines [1988] 2 All ER 77.

62 Ch 11, US Bankruptcy Code (11 USC s 1101-1174).

63 Named after the case of Mareva Compania Naviera SA v International Bulkcarriers SA, The Mareva [1975] 2 Lloyd's Rep 509.

64 S 304, US Bankruptcy Code (11 USC s 304). See Re Banco Ambrosiano Overseas Bkrtcy 25 BR 621 (1982), Interpool v KKL 102 BR 373 (1988) and Lindner Fund v Polly Peck International PLC 143 BR 807 (1992). 
...the English practice is to regard the courts of the country of incorporation as the appropriate legal forum for controlling the winding-up of a company but that, insofar as that company had assets here, the usual practice is to carry out an ancillary winding-up in accordance with our own rules, while working in harmony with the foreign courts. ${ }^{65}$

The case-law makes it clear that the courts retain a substantial discretion, particularly over whether to permit ancillary winding-up proceedings as in the case of Re Wallace Smith Group. ${ }^{66}$ The company in question was an authorised institution under the Banking Act 1987 which had been wound up on the application of the Bank of England. Further to this, four other companies, all members of the same group of companies, were the subject of winding-up petitions by the liquidators of the company. The petition relating to another company alleged substantial indebtedness in relation to the employment of two persons attributable in the inter-company accounts to that company. On the facts, the petition would be dismissed as to allow it would prejudice concurrent proceedings on the same issue in the Ontario courts. It is not the case that once indebtedness is shown, together with a connection with the jurisdiction and the possibility of benefit to creditors within the jurisdiction, that an ancillary winding-up order is automatic. The courts retained a discretion, one of the factors being whether there was a more appropriate jurisdiction for the claim. ${ }^{67}$ In a similar context, it has also been held that where the connection with the ancillary jurisdiction was fortuitous and the transfer of assets to the main jurisdiction could be effected without substantial cost, no purpose would be served by the granting of an ancillary winding-up order. ${ }^{68}$

The common law continues to develop rules to meet the inevitable challenges occasioned by the competing interests of the courts of several jurisdictions concerned with the activities of the same insolvent company. However, these

65 At 93-94 (per Mr Justice Hirst).

66 Re Wallace Smith Group [1992] BCLC 989.

67 Similarly in Re Wallace Smith [1992] BCLC 970 (If the connection with the ancillary jurisdiction was modest and the transfer of assets to the main jurisdiction could be effected without substantial cost, no purpose would be served by an ancillary winding-up order). See also Tong Aik (Far East) v Eastern Minerals and Trading (1959) [1965] 2 MLJ 149, where a Singapore court declined jurisdiction in favour of a Malaysian court. 
principles have to a greater or lesser extent been supplemented or supplanted by statutory provisions that are the subject of the following sections dealing with ancillary jurisdiction and co-operation measures. As will be seen, these common law principles continue to influence and dictate the extent of the judicial discretion that is exercised in the course of applying these statutory provisions and reflect views of whether courts themselves are keen to promote co-operation and assistance. Nonetheless, the common law continues to throw up cases that illustrate the willingness of courts to assist courts elsewhere where statutory provisions either do not exist or are limited in their scope. An interesting recent example is the case of Cambridge $\mathrm{Gas}{ }^{69}$ where bondholders of a group that had filed for Chapter 11 protection in the United States did not support the debtor's reorganisation plan and sought successfully to substitute their own. Enforcement of the rival plan was then sought before the courts in the Isle of Man where the parent company was located. In granting the order for recognition, the Privy Council, although recognising that assistance to a foreign office-holder was narrower than the statutory position represented by provisions such as section 426 of the Insolvency Act 1986, nonetheless the common law position in favouring universality of bankruptcy militated for recognition of the plan and for assistance in furthering its enforceability. ${ }^{70}$

\section{$4 \quad$ Statutory jurisdiction to wind up a foreign company}

\subsection{Introduction}

A jurisdiction conferred by statute has long existed in the United Kingdom for the winding-up of unregistered companies, which definition may include foreign corporations. ${ }^{71} \mathrm{~A}$ jurisdiction conferred by statute has long existed in England and Wales for the winding-up of unregistered companies, which definition has

69 Cambridge Gas Transport Group Corp v The Official Committee of Unsecured Creditors of Navigator Holdings PLC [2006] UKPC 26.

70 Walters 2007Co Law 73; Moss 2006 Insolv Int 123.

71 See s 32(3), Companies (Winding-Up) Act 1890 (UK) applying the act to companies without a registered office within the jurisdiction. See also Re Mercantile Bank of Australia [1892] 2 Ch 204. 
also been held to include foreign corporations. ${ }^{72}$ An early inclusion in the Joint Stock Companies Act 1848 sought to define, by reference to the location of the registered place of business or head office, the allocation of jurisdiction between Irish and English courts over the winding-up of companies. ${ }^{73} \mathrm{~A}$ more sophisticated section in 1862 legislation saw the introduction of statutory authority for the winding-up of any unregistered company in the part or parts of Great Britain, meaning England and Wales or Scotland, where it has a principal place of business. ${ }^{74}$ This section was repeated in the 1908 consolidation. ${ }^{75}$ The application of this provision to companies in existence and operating within the jurisdiction was not in doubt, the definition of unregistered company including the foreign company by default. ${ }^{76}$ However, this was not thought to be the case where the company had ceased to exist in accordance with a regular judgment or process in its jurisdiction of origin. This issue arose in cases before the courts in England because of the consequences of the 1917 October Revolution, following which the nationalisation of all Russian banks was decreed. The effect on creditors in England became apparent in the 1920s as various suits against banks established in Moscow with operations in London were struck out as wanting. ${ }^{77}$ A provision was introduced into the United Kingdom Companies Act 1929, which subsequently has been incorporated in the Companies Acts of Malaysia and Singapore, to provide for the winding-up of an unregistered company, was extended to cover the situation where a company, which though operating within the jurisdiction through a branch or other office, had been dissolved in its place of incorporation. ${ }^{78}$ Nevertheless,

72 Re Commercial Bank of India (1868) LR 6 Eq 517. See also s 32(3), Companies (WindingUp) Act 1890 (UK) applying the act to companies without a registered office within the jurisdiction and Re Federal Bank of Australia (1893) 62 LJ Ch 56.

73 S 117, Joint Stock Companies Act 1848 (UK).

74 S 199, Companies Act 1862 (UK).

75 S 268, Companies (Consolidation) Act 1908 (UK).

76 Re Jarvis (1895) 11 TLR 373 (Missouri company); Re Syria Ottoman Railway Company (1904) 20 TLR 217 (Turkish company). This definition is wide and also includes the situation of Northern Irish companies operating in England as decided in Re A Company (No 007946 of 1993) [1994] 2 WLR 438. See Smart 1996 ICLQ 177.

77 Lazard Brothers v Midland Bank [1933] AC 289 (Garnishee proceedings on assets in London of a bank dissolved in Russia held void on grounds of it ceasing to exist).

78 See s 338(2), Companies Act 1929 (UK) which reads: "Where a company incorporated outside Great Britain which has been carrying on business in Great Britain ceases to carry on business in Great Britain, it may be wound up as an unregistered company under this part of this Act, notwithstanding that it has been dissolved or otherwise ceased to exist as 
the operation of the provision was not without difficulty. It was not thought that it could extend to the situation where a company had ceased to exist before the passing of the act. Judicial intervention arrived in the shape of Russian and English Bank, ${ }^{79}$ which followed the situation where the Russian Ministry of Agriculture purchased seed from a Danish firm and requested the bank, incorporated in the form of a company in St Petersburg, to pay this sum through its London branch. Reimbursement was sought through payment, on Ministry of Finance instructions, by Barings to the bank. Barings failed to pay, prompting the bank to sue. It was discovered that the bank had been dissolved by Soviet legislation, and the suit was stayed for the commencement of winding-up proceedings. An action was then brought in the bank's name against Barings, which the latter sought to have struck out on grounds that the bank was a dissolved corporation. It was held in the case that a foreign company may, notwithstanding its dissolution in its place of origin, be wound up as an unregistered company in England, when an action may be brought in its name to recover moneys due and unpaid at the time of its dissolution. Lord Atkin, one of the members of the panel, opined it:

.... a necessary implication... that the dissolved foreign company is to be wound up as though it had not been dissolved and therefore continued in existence. ${ }^{80}$

This extension of jurisdiction was confirmed in Re Russian Bank for Foreign Trade, ${ }^{81}$ which concluded that the impossibility of a branch continuing to function when its main office had ceased to exist according to its statutes of incorporation was ample reason to order a winding-up. The consequences of the Russian Revolution were to haunt the law reports for many years after. In the case of Re Banque des Marchands de Moscou (Koupetschetsky), ${ }^{82}$ proceedings under later companies legislation, ${ }^{83}$ the claims of various creditors

a company under or by virtue of the laws of the country in which it was incorporated." See also s 315, CAM and s 351, CAS.

79 Russian and English Bank v Baring Bros [1936] AC 405.

80 At 427.

81 Re Russian Bank for Foreign Trade [1933] 1 Ch 745.

82 Re Banque des Marchands de Moscou (Koupetschetsky) (Royal Exchange Assurance v Liquidator) [1952] 1 All ER 1269; Idem (Ouchkoff $v$ Liquidator) [1954] 2 All ER 746.

83 S 399, Companies Act 1948 (UK). 
were held subject to Russian law and that the revival of the company for the purposes of winding-up could not revive claims which were barred by the nationalisation decree. The situation of confiscatory legislation, which over the years was encountered in a number of different instances, has been generally held not to operate so as to remove those obligations that the company had acquired within the jurisdiction where proceedings were being instituted, whether this company was the subject of liquidation proceedings or proceedings for the enforcement of debt as is the case in Metliss, ${ }^{84}$ where a Greek Decree 1949 enforced a moratorium on the National Mortgage Bank of Greece, which was subsequently dissolved in 1953 and amalgamated to form a new bank. The plaintiff sued this bank on certain bonds, disputes about which were expressed as being subject to arbitration in London according to English law. It was held that, although Greek law had to be examined to ascertain the nature of the juridical body being created by the decree, the succession of this body to obligations acquired by its predecessor and expressed as being subject to English law must be examined by principles of English law. In the instant case, the courts could not admit the bank's status as a justiciable person without admitting its liability for acts entered into by its predecessor.

Part of the consideration for exercising jurisdiction has been to look at the nature of the obligations situated within the jurisdiction. In $R e$ Compania Merabello ${ }^{85}$ it was stated that normally a case falling under the Companies Act envisaged no need to establish that the company had a place of business or that it had carried out business in the jurisdiction, but required a connection with the jurisdiction and the presence of some assets of benefit to creditors. The nature of these assets might be intangible, such as a right of action, the success of which need not be proved to obtain a winding-up order, as was the

84 Metliss v National Bank of Greece and Athens SA [1958] AC 509.

85 Re Compania Merabello San Nicholas SA [1973] 1 Ch 75 (Claim in respect of a contract of carriage of cargo, subrogated by insurers, against a creditor of the company with view to vesting the claim under the Third Parties (Rights against Insurers) Act 1930). This line of reasoning is of some vintage and the presence of substantial assets was deemed a requirement in Tong Aik (Far East) v Eastern Minerals Trading (1959) [1965] 2 MLJ 149. 
case in $R e$ Allobrogia, ${ }^{86}$ or might even consist of a potential claim against a statutory scheme, as in Re Eloc. ${ }^{87}$ Courts would be careful to exercise their discretion widely in these cases where there was some tangible benefit and would not restrict any order made to fetter the actions of officials acting under the direction of the court. ${ }^{88} \mathrm{~A}$ further qualification on whether the presence of assets is even necessary was decided in the case of Okeanos, ${ }^{89}$ where the tangible benefit consisted of the connection of the company with the jurisdiction and the likelihood that the creditors would obtain some benefit from the winding-up being carried out in the jurisdiction. ${ }^{90}$ Nevertheless, the issue of benefit remains of importance and continues to govern the case law. It was reiterated and been summarised in the case of Real Estate Development, ${ }^{91}$ where the requirements are for courts to determine the existence of a sufficient connection with the jurisdiction, a qualification that need not necessarily consist of assets, the existence of a reasonable prospect of benefit to those applying for the winding-up order and that one of the individuals concerned must be a person (natural or legal) over whom the court could take jurisdiction. Nevertheless, there remains the question of the appropriate action to take in cases where the assets at first sight appear intangible. In fact, the case of $R e$ Latreefers $^{92}$ is treated as authority for the proposition that even the summary of the jurisdictional requirements in Real Estate Development are not to be treated as preconditions for the exercise of jurisdiction. ${ }^{93}$ In line with the general move towards looking at the benefit to creditors rather than the preponderance of assets, courts in Singapore have also wound up foreign companies where there is in fact a "sufficient connection" with Singapore and there is a "reasonable

86 Re Allobrogia Steamship Corporation [1978] 3 All ER 425 (Claim by owners of a cargo against $A$ resulting from a contract of carriage, insured in the United Kingdom. Potential to sue for recovery of sum assured held to be a sufficient asset to found winding-up procedure).

87 Re Eloc Electro-Optieck and Communicatie BV [1982] 1 Ch 43 (Possibility of payment from statutory fund for employee redundancy contingent on company being wound up held sufficient benefit for order to be made).

88 Re Hibernian Merchants [1957] 3 All ER 97.

89 International Westminster Bank PLC v Okeanos Maritime Corp [1987] BCLC 450.

90 See Dine 1988 Co Law 30.

91 Real Estate Development [1991] BCLC 210.

92 Re Latreefers [1999] 1 BCLC 271, on appeal sub nom Stocznia Gdanska SA v Latreefers [2000] EWCA Civ 36 (9 February 2000). See Dawson 1999 Co Law 304.

93 See par 30 of the judgment. 
possibility of benefit" that may accrue to creditors in proceedings. ${ }^{94}$ Nevertheless, it is still the case courts will not accede to an order for ancillary liquidation, where there is doubt as to whether substantial assets located in the jurisdiction do in fact have a connection to the company in question and that proceedings already in progress in the company's home jurisdiction would be competent to determine this question. ${ }^{95}$

\subsection{Provisions for exercising jurisdiction}

The law relating to insolvency, contained in the Companies Acts of Malaysia and Singapore, is derived in part from the Australian Uniform Companies Act 1961, itself re-codified in 1981, 1989 and again in $2001 .^{96}$ In parallel with the Australian legislation, both the Malaysian and Singapore Acts contain two separate sets of provisions dealing with jurisdiction over a foreign company, the first where that company has registered to conduct business within the jurisdiction and second, if a company falls outside the foregoing provisions, where it falls within the definition of an unregistered company. This second provision was originally introduced into the United Kingdom Companies Act 1929, which influenced the Australian legislation and subsequently became incorporated in the Companies Acts of Malaysia and Singapore, to provide for the winding-up of an unregistered company. This provision was later extended to cover the situation where a company had been dissolved in its place of incorporation. ${ }^{97}$

94 See Lee http://www.aseanlawassociation.org/ 31 Aug, citing Re Griffin Securities Corporation [1999] 3 SLR 346.

95 New Hampshire Insurance Co v Rush and Tompkins Group PLC and another [1998] 2 BCLC 471.

96 In the Companies Code 1981, the Corporations Act 1989, retitled Corporations Law by the Corporations Legislation Amendment Act 1990, and the Corporations Act 2001 (hereafter CAA).

97 S 338(2), Companies Act 1929 (UK). See s 315, CAM and s 351, CAS. 


\subsubsection{Specific jurisdiction to wind up a foreign registered company}

The law provides that companies wishing to conduct business in Malaysia or Singapore must not carry out business in these countries unless they have been registered or are about to register with the appropriate authority. ${ }^{98}$ The law provides that where a registered foreign company goes into liquidation, or has been dissolved, in its home jurisdiction, any person who is a local agent of the foreign company must lodge notice of that fact and notice of the appointment of a liquidator, where one is appointed, within a time period of one month calculated by reference to the dissolution or the beginning of winding-up proceedings. $^{99}$ The person who has been appointed liquidator in the foreign jurisdiction enjoys the powers of a local liquidator until one is appointed by court. $^{100}$ Authority suggests that a foreign liquidator does not become the liquidator for Singapore merely because he is given the powers of this latter post. ${ }^{101}$ This would suggest that appointment of a liquidator in Malaysia or Singapore would result in the revocation of any order vesting title to property in the foreign liquidator made by a local court.

A liquidator of a foreign company appointed by the courts must invite all creditors to make their claims against the foreign company within a reasonable time before any distribution of the foreign company's property is made. This is usually performed by advertising in a daily newspaper circulating generally in any country where the foreign company has carried on business at any time prior to liquidation, except in any particular jurisdiction where a liquidator has in fact been appointed. ${ }^{102}$ In addition, the liquidator may not pay out a creditor of the foreign company to the exclusion of another creditor of the foreign company

98 S 332, CAM; s 368, CAS.

99 S 340(2)(a), CAM; s 377(2)(a), CAS; s 601CL(14)(a), CAA. In Australia, the courts have the power to entertain an application by the Securities Commission or the person who is the liquidator for the foreign company in its home jurisdiction to appoint a liquidator of the foreign company in Australia. This power is curiously absent from the draft of both the CAM and CAS.

100 S 340(2)(b), CAM; s 377(2)(b), CAS; s 601CL(14)(b), CAA.

101 Re China Underwriters Life and General Insurance [1988] 1 MLJ 409 at 413D (per Chan Sek Keong jc). Arguably, this analysis also holds true for the Malaysian provision.

102 S 340(3)(a), CAM; s 377(3)(a), CAS; s 601CL(15)(a), CAA. In Australia, 6 years is the upper limit for ascertaining if a foreign company has conducted business in any particular state or territory. 
without obtaining a court order authorising him to do so. ${ }^{103}$ Any payments that are made will be in accordance with domestic rules for the ranking and payment of claims. ${ }^{104}$ The liquidator is required to recover and realise all property belonging to the foreign company in Malaysia or Singapore and pay the net amount to the liquidator of the foreign company for its home jurisdiction unless the courts otherwise order. Nevertheless, this is subject to a local 'grabrule', by which the net amount is paid after paying any debts and satisfying any liabilities within the jurisdiction. ${ }^{105}$ Commentators are divided about the effect of local grab-rules, suggesting that this type of territorial approach runs counter to the accepted pari passu principle and equality of treatment. In international insolvency proceedings, it is argued that only very diligent creditors will be able to participate and prove in a number of insolvencies and smaller creditors, unless fortuitously present in the jurisdiction applying the grab-rule, will lose out. This results in an element of unpredictability in international business leading to increased transaction costs in financing and insurance arrangements. This view is echoed locally by Lee, who suggests that the grabrule is an "unsatisfactory feature" of the law in Singapore, which appears to be out of step with current international standards and the traditional position at common law, which normally accepts the pari passu principle, thus meriting consideration as part of possible reforms. ${ }^{106}$

There is authority to suggest that grounds for a court refusing to allow repatriation of assets may arise where, for example, there is a risk that the liquidator in the foreign company's home jurisdiction might not divide assets equitably. ${ }^{107}$ Where there is no liquidator for the home jurisdiction, the liquidator may apply to the Court for directions about the disposal of the net amount recovered following winding-up of the registered foreign company insofar as its

103 S 340(3)(b), CAM; s 377(3)(b), CAS; s 601CL(15)(b), CAA.

104 S 292, CAM; s 328, CAS.

105 S 340(3)(c), CAM; s 377(3)(c), CAS. See s 601CL(15)(c), CAA, which does not apply the grab-rule.

106 Lee supra n 94 at 330-331, citing Tohru Motorbayashi v Official Receiver [2000] 4 SLR 529.

107 Re Australian Life and General Assurance Company [1931] VLR 317. 
property in Malaysia or Singapore is concerned. ${ }^{108}$ Proceedings under the specific jurisdiction rule are generally treated as being ancillary to proceedings being conducted in the foreign company's home jurisdiction. ${ }^{109}$ As the definition in the law uses the term 'place of incorporation or origin', it is submitted that where there is evidence that the company has closer attachments to another jurisdiction in which incorporation was not actually carried out, proceedings in that jurisdiction will be treated as primary proceedings, to which a liquidation in Singapore or Malaysia will be ancillary. Nevertheless, these rules may not be of application where there are no proceedings in the home jurisdiction or these proceedings fall short of what are considered liquidation proceedings. In addition, there is doubt that this provision applied in situations where the foreign company has not in fact registered to conduct business. ${ }^{110}$

\subsubsection{The general jurisdiction rule}

Additional jurisdiction in Malaysia and Singapore to wind up a company not incorporated in these jurisdictions is available in Division 5 of Part $X$ of the respective acts. These rules apply to what are termed 'unregistered companies', defined to include a foreign company and any partnership association or company consisting of more than five members, but not include a company incorporated under the act. ${ }^{111}$ The rules in this part are stated to be in addition to and do not supersede any provisions contained in the act or any other law dealing with the winding-up of companies. The same powers are, in fact, given to the courts or appointed liquidator to perform any act in the case of a company falling under these rules as is normally performed in respect of the winding-up of companies. ${ }^{112}$ As a general principle, an unregistered company

108 S 340(4), CAM; s 377(4), CAS; s 601CL(16), CAA.

109 Re Commercial Bank of South Australia (1886) 33 Ch D 174; Re English, Scottish and Australian Chartered Bank [1893] 3 Ch 385.

110 Cooper and Jarvis supra n 42 at 6 state that as a rule "where a foreign company is not registered in Australia, ancillary proceedings may not be commenced". UK Tobacco (1929) $\checkmark$ Malayan Tobacco Distributors [1933] MLJ 1 is authority to suggest that registration is an obligation, although failure to register does not make the company an illegal association or prevent it from enforcing any rights it may have.

111 S 314(1), CAM; s 350(1), CAS. In Woon and Hicks supra n 33 at par 2:5734, it is pointed out at that the Singapore text inserts a comma between the words 'partnership' and 'association', thus possibly changing the import of the provision.

112 S 314(2), CAM; s 350(2), CAS; s 582(1), CAA. 
may be wound up notwithstanding that it is being wound up or has been dissolved or has otherwise ceased to exist as a company by virtue of the laws of the place where it was incorporated. ${ }^{113}$

An unregistered company may be wound up under Part $X$, which deals with winding-up in general, subject to certain necessary adaptations. These include, in relation to foreign companies, the fact that the principal place of business in Malaysia or Singapore for the purpose of winding-up is taken to be the registered office of the foreign company and that a foreign company may not be subject to voluntary winding-up. ${ }^{114}$ Proof that a foreign company is in fact carrying on business in Malaysia or Singapore is to be inferred from the establishment of a share transfer or registration office or frequent dealings with property in the jurisdiction as an agent, legal personal representative or trustee. ${ }^{115}$ Activities which of themselves do not signify that the foreign company is carrying out business include acting as a party to legal proceedings, holding company meetings in Malaysia or Singapore, maintaining a bank account, effecting a sale through an independent contractor, creating security over property or debt, collecting or enforcing rights over debt, investing funds or holding property, procures the conclusion of contracts binding outside these countries and conducting a single or isolated transaction within a 31-day period, unless this transaction is one of a similar series conducted over a period of time. ${ }^{116}$ In addition, in Malaysia, the temporary importation of goods for a display or exhibition with view to re-export is not considered to amount to carrying on business. ${ }^{117}$

Circumstances in which an unregistered company may be wound up include where it is unable to pay its debts, where it has been dissolved, where it has ceased to carry on business in Malaysia or Singapore, where it has a place of business in these countries only for the purpose of winding-up its business and

113 S 315(3), CAM; s 351(3), CAS; s 582(3), CAA.

114 S 315(1)(a)-(b), CAM; s 351(1)(a)-(b), CAS; s 583(a)-(b), CAA.

115 S 330(1), CAM; s 366(1), CAS.

116 S 330(2), CAM; s 366(2), CAS.

117 S 330(2)(j), CAM. 
where the court is of the opinion that it is just and equitable that it should be wound up. ${ }^{118}$ Instances in which an unregistered company is deemed to be unable to pay its debts include where it fails to pay or otherwise secure or compound within three weeks following the presentation of a demand made by a creditor for payment of a sum in excess of the statutory set amount, where it fails to take steps upon the service of notice of an action or other proceedings by another party on either a shareholder or the company concerned by paying any debt due or taking steps to meet any demands which have been made, where execution or enforcement of a judgment obtained in any court has not been satisfied by the company and, lastly, where it is proved to the satisfaction of the court that the company is unable to pay its debts. ${ }^{119}$

Following dissolution of an unregistered company, where any property belonging to that body remains in Malaysia or Singapore, the legal or equitable estate or other interest in that property, together with any claim, right or remedy affecting that property will vest in the person entitled under the law of the company's place of incorporation or origin. ${ }^{120}$ Where the place of origin is Malaysia or Singapore, which may be the case of partnership associations or other types of company, local rules on the distribution of the assets of defunct companies will apply. ${ }^{121}$ An element of reciprocity is required for the operation of this section as the place of origin must be a country, designated by the Government Minister responsible as having laws containing provisions similar to those set out in these rules. ${ }^{122}$

\subsubsection{Additional considerations for exercising jurisdiction}

As noted earlier, the development of common law principles for the exercise of jurisdiction over foreign companies has permeated the exercise of statutory

118 S 315(1)(c), CAM; s 351(1)(c), CAS; s 583(c), CAA.

119 S 315(2), CAM; s 351(2), CAS; s 585, CAA.

120 S 318(1), CAM; s 354(1), CAS.

121 S 318(2), CAM; s 354(2), CAS.

122 S 318(3), CAM; s 354(3), CAS. See s 588, CAA, which provides that the property will vest in the Securities Commission, unless the part 5.7 body (broadly equivalent to the unregistered company) is incorporated in Australia, when it vests in the person entitled by the law of the body's place of origin. 
jurisdiction through the influence over judicial discretion. As will be seen below, three areas in particular have seen further development in this context.

(a) Further jurisdictional requirements

It is stated that the existence of a place of business in Singapore is not necessary for the exercise of jurisdiction to wind up an unregistered, or foreign, company. A winding-up order may be made as long as assets are present within the jurisdiction. As an alternative, there may be persons present within the jurisdiction who have a legitimate interest in the proper distribution of a company's assets. ${ }^{123}$ A broad view is taken of the definition of assets, so as to include rights pertaining to a cause of action. ${ }^{124}$ This view is not universal in all common law jurisdictions. It may be instructive to note that commentators in Australia argue that it is necessary to show stronger evidence of a connection with the jurisdiction. Often, determining whether the evidence shows the type of connection necessary may be complex, as Australian case-law illustrates in $R e$ Norfolk. ${ }^{125}$ A shipping company, incorporated on Norfolk Island, operated between Sydney and ports in New Zealand via Norfolk Island. Its sole asset, a ship, was stranded in Auckland. The company had not registered in New South Wales as a foreign company and did not have an office in New South Wales, its affairs being managed by an agent company, incorporated in that jurisdiction. In proceedings hearing a winding-up petition, the court considered whether it had jurisdiction and held that the domestic provisions clearly applied to foreign companies if these were subject to registration, which was required if the company wished to establish a place of business or carry out business in New South Wales. Although the company had no place of business or any office in the jurisdiction, the court formed the view that the company did in fact carry on business in New South Wales, which it based on the observation that the

123 Woon and Hicks supra n 33 at 2:5828, citing as authority Banque des Marchands de Moscou (Koupetschesky) v Kindersley [1951] Ch 112.

124 Re Compania Merabello San Nicholas SA [1973] Ch 75; Re Allobrogia Steamship Corp. [1978] 3 All ER 423.

125 Re Norfolk Shipping Line (1988) 6 ACLC 990. 
company carried out, through its agent, more than a limited number of isolated transactions with view to pecuniary gain.

On the question of the appropriateness of exercising jurisdiction, the court concluded that there must also be a proper commercial connection with the jurisdiction, defined to include the presence of assets and personnel within the jurisdiction competent to distribute the assets concerned, as well as a reasonable possibility that benefit would accrue to creditors from a winding-up order being obtained in that jurisdiction. ${ }^{126}$ The court could not establish the presence of any assets within the jurisdiction with any certainty and could not hold that creditors owed a total amount of more than a million dollars would benefit. The court thus had doubts as to whether the presumptions under the law were met but justified appointment of a provisional liquidator under other legislation. ${ }^{127}$ In the above case, the court opined that the law with respect to whether assets, whether these are negligible or not, are required as a basis of jurisdiction is not yet certain. ${ }^{128}$ There is further authority to suggest that a winding-up will only be ordered if there are assets present within the jurisdiction, ${ }^{129}$ although the New South Wales Supreme Court has in fact made an order in respect of an insolvent foreign company with negligible assets in Australia where almost all of the creditors were resident within the jurisdiction. $^{130}$ The question of whether the existence of assets and concomitant benefit to creditors as grounds for jurisdiction is necessary has also been raised by commentators. ${ }^{131}$ This argument has also been raised in Singapore, where the trend has been to minimise the asset test and look instead to the potential benefit to creditors of proceedings. ${ }^{132}$

126 Following Re Compagnia Merabello San Nicholas SA [1973] Ch 75 and Re A Company (No 00359 of 1987) [1988] 1 Ch 210.

127 Furthermore, in a related case: Re Atlantic Isle Shipping (1988) 6 ACLC 992, a provisional liquidator was appointed for a connected company on the basis of the presence of minimal assets and the bare minimum of evidence suggesting the company did in fact carry on business in New South Wales.

128 At 991 (per Young j).

129 Re Kailis Groote Eylandt Fisheries Pty Ltd [1977] 2 ACLR 574.

130 Re Buildmat (Australia) Pty Ltd (1981) CLC 40-714.

131 See Grace 1986 ICLQ 689, citing in support Banque des Marchands de Moscou v Kindersley [1951] 1 Ch 112 and Re Azoff-Don Commercial Bank [1954] Ch 315.

132 Lee supra $\mathrm{n} 94$. 
(b) Discretion to refuse a petition

The granting of an order following a winding-up petition is said to involve the exercise of a court's discretionary powers. This is firmly established in local law, following the decision in Tong Aik. ${ }^{133}$ In this instance, an appeal was brought to the Federal Court in Singapore against the decision of the High Court refusing to make an order for the winding-up of the Eastern Minerals \& Trading (1959) Ltd company. The appellant was unable to obtain payment of a judgment debt and evidence to support the contention that the company was unable to pay its debts appeared in an affidavit sworn by one of the respondent's directors. The company was incorporated under the Companies Ordinance of the States of Malaya and had its registered office in the state of Kelantan. Although it had maintained a place of business in Singapore, by the time of the petition it had notified the Registrar of Companies that it had ceased to maintain its place of business. It was thus considered an unregistered company and fell to be wound up under the appropriate rules in Singapore. ${ }^{134}$ Evidence was nevertheless available to the court suggesting that the company's sole activity was carrying out mining in Kelantan and that the company had minimal assets in Singapore, although there were substantial outstanding liabilities. The court's view was that the effect of an order made by a Singapore court was necessarily limited to assets present within the jurisdiction and no useful purpose would be served if there were indeed no assets present. That fact was sufficient in itself to deny the appeal, although the court also noted that there was nothing to prevent a petition being brought in the States of Malaya and that the relevant companies enactment provided for the due administration of assets. Furthermore, the companies enactment contained a reciprocal provision allowing a winding-up order made by one jurisdiction to be acted on in the other without the necessity for formal winding-up proceedings to be opened. ${ }^{135}$ 
(c) Forum non-conveniens/Lis alibi pendens

Although rarely invoked in the context of insolvency proceedings, a plea of forum non conveniens or lis alibi pendens may be raised where litigation is already in contemplation or has been initiated on an issue which will be affected by the onset of insolvency proceedings, especially where the rules of insolvency proceedings prevent the determination of issues, including the fate of priorities, set-offs, and dispositions of assets, except by application of insolvency principles. This may result in great detriment to an individual creditor in comparison to the benefit available for all creditors as a class. This is of particular relevance where the court is petitioned to open winding-up proceedings in respect of a foreign company on just and equitable grounds. ${ }^{136}$

The Malaysian and Singapore views on the doctrine of forum non conveniens are broadly similar to that in English law, where it is a relatively recent development. ${ }^{137}$ Under previous common law rules, a stay of action would only be granted in cases of vexation or oppression. ${ }^{138}$ The basic principle is that a stay will only be granted where the court is satisfied that there is another available forum that is the appropriate forum for trial and that the case may be tried more suitably in that forum in the interest of all the parties and of justice. The burden of proof is on the defendant to show that there is another forum that is more appropriate than the English forum. Factors to be taken into account include with which country the action has the most real and substantial connection, the law governing the relevant transaction, the place where the parties reside or carry on business and questions of convenience and expense, although it is not enough to show that the plaintiff will obtain a personal or legal advantage by the action remaining within the jurisdiction. ${ }^{139}$

136 Grace supra n 131 at 689 ( $\mathrm{n} 230$ cites as authority Mills v Mills (1938) 60 CLR 150).

137 The Atlantic Star [1974] AC 436.

138 Logan v Bank of Scotland (No 2) [1906] 1 KB 141.

139 Spiliada Maritime Corp v Cansulex [1987] AC 480. The position in Malaysia and Singapore is broadly analogous to the English rules. 


\section{$5 \quad$ Mutual assistance measures: co-operation with foreign courts}

The move away from statutory jurisdiction of the ancillary type to more complex co-operation measures seems to have been initiated largely because of the perceived inadequacy of submitting a foreign company to domestic jurisdiction without necessarily involving the consent of the jurisdiction of origin. The development of the doctrine of comity, requiring courts to have regard for the decisions given by courts of comparable status and to enforce them, further stimulated progressed towards co-operation by inviting courts to make contact with each other and to develop working relationships, so as to be able to ascertain what outcome was feasible within the context of proceedings involving matters of joint concern. Furthermore, the development and expansion of corporate rescue measures meant that ancillary jurisdiction, geared as it was towards the liquidation of assets, was inadequate to deal with the problems of the preservation and continuing exploitation of assets necessary for ensuring the survival of businesses in financial difficulties. In these instances, co-operation was vital to allow corporate rescue measures to have effect. Co-operation measures have a long history and are known in a number of jurisdictions from about the middle of the $19^{\text {th }}$ century. In this context, it may be noted that the development of co-operation provisions occurred initially within the field of bankruptcy, where perhaps the need was first felt. This has influenced, in many jurisdictions, the adoption of comparable measures to assist corporate debtors.

\subsection{Introduction}

The history of the provision is largely that of the development of co-operation measures in the context of the bankruptcy of individuals. There is in fact a long tradition in the common law of courts extending aid for the collection of assets located in the jurisdiction of the courts and that belong to foreign debtors. ${ }^{140}$

140 Solomons $v$ Ross (1764) 1 Hy BI 131n; 126 ER 79. See Nadelmann 1947 ModLR 154; Lipstein 1949 ModLR 454. For an extensive survey of this development, see Blom-Cooper 1954 ICLQ 604, 1955 ICLQ 1 and 170 (part 1, 2 and 3). 
The precept of assistance, first located within the law of bankruptcy, derives from the doctrine relating to the law of personality or movable property, by which personal assets were deemed to have no locality but were subject to the law governing the person of the owner. ${ }^{141}$ There were difficulties, however, in relation to persons who had not committed acts of bankruptcy within the jurisdiction. ${ }^{142}$ Furthermore, the situation of real property was one where the courts often declined to assume jurisdiction, holding that the proper law was that of the location. ${ }^{143}$ Nevertheless, the opening of proceedings involving foreign debtors began to be a regular feature in the case-law, although the courts were not always inclined to give effect to foreign judgments in all cases. $^{144}$ Nonetheless, the common law development of assistance in bankruptcy began to give way to statutory formulations incorporating an assistance doctrine.

The first appearance of a statutory formula can be traced to $19^{\text {th }}$ century provisions on enforcement of orders given by courts within the United Kingdom and a requirement of assistance to other British courts, perhaps embodied in bankruptcy legislation as a response to the growing numbers of insolvencies of persons and partnerships affecting assets located in a number of Commonwealth jurisdictions. ${ }^{145}$ Interestingly, the 1849 Act, which was a Consolidation Act embodying an update of bankruptcy law, contained a section 75 that stated that the filing of a bankruptcy petition and adjudication of an act of insolvency in India was to be treated as conclusive evidence of an act of bankruptcy for proceedings in England. Although the definition of Indian territory did not appear to extend to other colonies or settlements then ruled from India, including the Straits Settlements, a further section 239 did provide that copies of petitions (including vesting orders, schedule of debts,

141 Sill v Worswick (1781) 1 H BI 665, 690 (per Lord Loughborough).

142 See Topham 1903 LQR 295.

143 British South Africa Company v Companhia de Mocambique [1893] AC 602; Re Trepca Mines [1960] 3 All ER 304.

144 Tharsis v La Société des Métaux (1889) 58 LJ QB 435; Gibbs and Sons v Société Industrielle et Commerciale des Métaux (1890) 25 QBD 399.

145 S 220, Bankruptcy Act 1849 (UK); s 73-74, Bankruptcy Act 1869 (UK); s 117-118, Bankruptcy Act 1883 (UK). See Graham 1989 CLP 217, 225 and Galbraith v Grimshaw [1910] AC 508 for a cross-border instance (England-Scotland) under the Bankruptcy Act $1883(\mathrm{UK})$. 
adjudication and other orders) that were issued in Calcutta, Madras and Bombay (collectively known as the Presidency Towns) as well as in the Prince of Wales Island (now known as Penang), Singapore and Malacca were to be treated as acceptable evidence before English courts of a foreign bankruptcy. This is the first mention of the extension to territory that is now comprised within Malaysia and Singapore of a recognition provision. The successor 1861 Act extended the remit of section 75 of the 1849 Act, coincidentally re-enacted as section 75 of the 1861 Act, to provide that the filing of a petition or adjudication of an act of insolvency in any court (including that of a colony, dominion or dependency) was now to be treated as conclusive evidence of an act of bankruptcy for proceedings in England. A further section 218 allows for petitions or orders in bankruptcy to be used directly as the basis of new adjudications of bankruptcy in England. Although section 239 of the 1849 Act becomes section 206 of the 1861 Act with no substantial change in wording, new sections 208 and 220 articulate what becomes known as the auxiliary doctrine, the first stating that courts in London and districts would be auxiliary for the purposes of administering oaths on affidavits or declarations, while other courts (in Scotland, Ireland or a colony, dominion or dependency) were able to take judicial notice of same, the second provision enabling courts in London and districts to be auxiliary for purposes of proofs of debt, examinations on oath "or for other like purposes" to other courts elsewhere.

The 1869 Act states in rather florid language a wording that has been used as the basis of subsequent co-operation provisions. In section 74 :

The London Bankruptcy Court, the local Bankruptcy Court, the Courts having jurisdiction in bankruptcy in Scotland and Ireland, and every British Court elsewhere having jurisdiction in bankruptcy or insolvency, and the officers of such Courts respectively, shall severally act in aid of and be auxiliary to each other in "all matters of bankruptcy", and an order of the Court seeking aid, together with a request to another of the said Courts, shall be deemed sufficient to enable the latter Court to exercise, in regard to the matters directed by such order, the like jurisdiction which the Court which made the request, as well as the Court to which the request is made, could exercise in regard to similar matters within their respective jurisdictions. 
This appears to permit full co-operation for bankruptcy matters between courts within the Empire (now Commonwealth) without distinction. However, the expansive language of the section required interpretation and an early case qualified the courts included within the definition by emphasising that the scope of the law was limited to courts that had jurisdiction in bankruptcy. ${ }^{146}$

Nevertheless, an early instance of their use saw a British court give effect to a pooling arrangement for creditors of a firm pursuant to a request from an Indian court despite the lack of express provision in the successor 1883 Act to give effect to such a scheme. ${ }^{147}$ It is also in the 1883 Act that the language changes slightly to reflect alteration to the internal court system in England, section 118 referring to "The High Court, the County Courts...". In fact, David Graham QC states that in the wake of the 1883 Act, the problem of bankruptcy co-operation within the British Empire had "taken centre stage" with "several draft bills", prepared by the Board of Trade (now Department of Trade and Industry) and a former Chief Justice of Australia being submitted to the Imperial Conference (the predecessor to the Commonwealth Heads of Government Meeting) in 1887. No progress was, however, made. ${ }^{148}$ As a result, the 1883 provision ends up simply consolidated as section 122 of the Bankruptcy Act 1914.

The provisions of this act were designed to co-ordinate proceedings and enabled the courts within the Commonwealth to request other courts to assist in the management of bankruptcy proceedings within their own jurisdiction. The making of an order seeking the aid of another court was deemed sufficient authority to enable the other court to exercise the jurisdiction it would if the matter were before it for consideration. The use of the word 'British' as part of the definition prompted enquiries in the United Kingdom in a number of cases as to whether particular courts were included. ${ }^{149}$ The same enquiry was put

146 Callender Sykes v Colonial Secretary of Lagos [1891] AC 460.

147 Re P. MacFadyen, ex parte Vizianagaram [1908] 1 KB 675.

148 See Graham 2001 IIR 153, 159.

149 Re Maundy Gregory (1934) 103 LJ Ch 267 (Jerusalem District Court included); Re Osborne [1931-32] B\&CR 189 (Manx Court included); Re James [1977] 1 All ER 364 (post-UDI Rhodesian courts excluded); Re A Debtor [1981] Ch 384 (Jersey Court included). 
before a number of Commonwealth courts as to whether they fell within the definition. ${ }^{150}$ Furthermore, the remit and purpose of the section were considered in $\operatorname{Re} A$ Debtor, ${ }^{151}$ in which it was held that the definition of 'bankruptcy' referred to the judicial process dealing with insolvent persons and was to be construed in a wide sense as the section was designed to produce co-operation between courts acting under different systems of law. Once an English court was satisfied the request for aid fell within the ambit of the provision, there was no general duty to scrutinise anterior proceedings unless it could be shown that they were defective under the proper law of the court or that they offended against public policy, thus setting a favourable trend for cooperation measures. This did not mean, however, that courts would not set conditions on the assistance given, particularly where there were interests within the jurisdiction that could potentially come into conflict. ${ }^{152}$

Particular difficulties exist where the foreign bankruptcy contains a sizeable revenue debt. ${ }^{153}$ As the nations constituting the Commonwealth became responsible for their own legislation, a situation given effective recognition by the Statute of Westminster 1931, the efficacy of judicial assistance depended wholly on courts recognising the similarities of the procedures each system evolved to deal with insolvency practice within their own jurisdiction. As noted earlier, the Bankruptcy Act 1883 and its successor consolidation legislation, the Bankruptcy Act 1914, were exported to a number of Commonwealth countries, including Malaysia and Singapore, incidentally ensuring the survival of the cooperation provision in these and other Commonwealth jurisdictions.

150 Contra: Re Graham [1928] 4 DLR 375 (Saskatchewan); Pro: Re Nall (1899) 20 NSWR 25, Re Greenaway (1910) WN (NSW) 112 (New South Wales); Re Fogarty (1904) QWN 67 (Queensland) and see Clunies-Ross v Totterdell (1988) 98 ALR 245, where the Australian court held that the definition applied to the Cocos Keeling Islands for the purpose of assistance to an Australian court.

151 Re A Debtor (ex parte the Viscount of the Royal Court of Jersey) [1980] 3 All ER 665.

152 Re Osborne [1931-32] 15 B\&CR 189; Re Jackson (1973) NILR 67. See also Re Gibbons (1960) Irish Jurist 60, where discretion was exercised against granting aid under the equivalent Irish provision: s.71, Bankruptcy (Ireland) Act 1872.

153 Government of India v Taylor [1955] AC 491. 


\subsection{Bankruptcy}

In Malaysia, the successor provision is now contained within bankruptcy legislation and deals with the reciprocal recognition and enforcement of bankruptcy judgments and orders of other countries. The reconsolidation of bankruptcy law in Singapore in 1995 saw the re-enactment of the corresponding provision with some textual amendments. ${ }^{154}$ The sections are principally designed to ensure close cooperation between Singapore and Malaysian courts, given the close historical links between the two countries as they permit the mutual recognition of acts by the Official Assignee without further formality. ${ }^{155}$ The sections permit the High Court of each jurisdiction to act in aid of and be auxiliary to the courts of the other jurisdiction as well as the courts of any other designated country with jurisdiction in bankruptcy and insolvency matters, provided that these courts are required to act in aid of and be auxiliary to the courts in either Malaysia or Singapore. ${ }^{156}$ Countries may be designated by the respective authorities through notification in the official Gazette of Malaysia or Singapore. ${ }^{157}$ An order of any such court seeking aid through a request to the High Court is deemed sufficient to allow the High Court to exercise jurisdiction in respect of the matter. This jurisdiction may be that which the High Court or the other court could exercise in comparable matters within their respective jurisdictions. ${ }^{158}$ One notable difference between the legislation in Malaysia and Singapore is the inclusion in the Malaysian Act of an extra sub-section stating that any discretion exercised by the High Court in matters of aid must have regard to the rules of private international law. ${ }^{159}$ In relation to the work of the Official Assignee, the provisions in Malaysia and Singapore require notification in the Gazette that the respective Governments

154 S 104, BAM; s 151, BAS.

155 For a working example, see Amos William Dawe v Development and Commercial Bank [1981] MLJ 230.

156 S 104(1), BAM; s 151(1), BAS. The use of the words 'bankruptcy and insolvency' in both texts suggest, if the ordinary meaning of the words are followed, that corporate insolvency is included in the definition, although s 121, BAM excludes the possibility of receiving orders being made against companies and the language of s 104(3)-(6), BAM only speaks of the Official Assignee in Bankruptcy, leading one to assume a contrario that it was not intended that companies should be covered by this provision.

157 S 104(7), BAM; s 151(3), BAS.

158 S 104(2), BAM; s 151(2), BAS.

159 S 104(2A), BAM. 
have entered into an agreement for the mutual recognition of each other's Official Assignee. ${ }^{160}$ Recognition would automatically allow property in any jurisdiction to be vested in the Official Assignee appointed in the other jurisdiction where proceedings have been opened in respect of the debtor in that other jurisdiction. ${ }^{161}$ An exception is made for property in any jurisdiction where there are pending proceedings in that jurisdiction until and unless those proceedings have been withdrawn or dismissed. ${ }^{162}$ To facilitate recognition, the production by courts in either jurisdiction of an order of bankruptcy is deemed conclusive proof in the courts in the other jurisdiction of the order having been made. ${ }^{163}$ Furthermore, the Official Assignees of either jurisdiction may sue in their own titles in the courts of the other jurisdiction. ${ }^{164}$ The way in which these provisions are stated is very similar to other comparable successor provisions, including the Australian and the British. ${ }^{165}$ However, the comparative lack of case-law suggests that the provision is little known or invoked in the context of cross-border insolvency. This may well explain the absence of any legislative or political pressure to improve its use or, as in both Australia and the United Kingdom, to extend the model to situations of corporate insolvency. ${ }^{166}$ Despite this, one commentator in Malaysia has advocated, for the reason that bankrupt parties are known to leave the jurisdiction rather than face judgment, that other countries, especially member states of ASEAN, be gazetted as designated countries for the purposes of section 104 and that consideration also be given to extending its use to corporate insolvency matters. ${ }^{167}$ Furthermore, what is interesting is that, as will be seen immediately below, at one time there was a co-operation model in corporate insolvency in Malaysia and Singapore.

160 S 104(3), BAM; s 152(1), BAS.

161 S 104(4), BAM; s 152(2), BAS.

162 S 104(4), BAM; s 152(3), BAS.

163 S 104(5), BAM; s 152(4), BAS.

164 S 104(6), BAM; s 152(5), BAS.

165 S 29, Bankruptcy Act 1966 and s 426, Insolvency Act 1986 (UK) respectively.

166 The s 29 model has been extended through its enactment mutatis mutandis in s 581, CAA, while the s 426 model, following the recommendations of the Report of the Review Committee on Insolvency Law and Practice, applies to both personal and corporate insolvency.

167 See Bte Abdullah http://www.aseanlawassociation.org/ 31 Aug. 


\subsection{Corporate Insolvency}

Part XIII of the former Companies Ordinance, one of the predecessors to the Companies Acts of both Malaysia and Singapore, contained provisions by which a winding-up order made by one of the jurisdictions over a company incorporated in that jurisdiction had effect in the other jurisdiction without the necessity for formal winding-up proceedings. ${ }^{168}$ These provisions were stated as applying on the basis of reciprocity and would allow for Official Receivers or other officials appointed in either jurisdiction to act in the other without further formality. ${ }^{169}$ Courts would be able to take judicial notice of authenticating documents issued under the seal of signatures of court officials in the other jurisdiction. ${ }^{170}$ The powers contained in the provisions were expressed as being in addition to any other remedies created by legislation or made available by the courts. ${ }^{171}$ The courts were empowered to transmit winding-up orders to the other court for action and aid in enforcing the order through the making of an ancillary winding-up order. ${ }^{172}$ Nevertheless, creditors were still permitted to apply for a stay before the ancillary order was given. ${ }^{173}$ The effect of an ancillary order was to render any attachment, distress or execution against the assets of the company void. ${ }^{174}$ No further action or proceeding would be permitted to commence or proceed without the leave of the court. ${ }^{175}$ The Official Receiver in the jurisdiction where the ancillary order was made would assume the role of an ancillary liquidator and may exercise all the powers of the Official Receiver to take possession of property, get in and realise assets, carry on the business of the company, pay claims and take proceedings on behalf of

168 Part XIII, s 342-356, Malayan Union Companies Ordinance 1946 (MU 13 of 1946) (hereafter $\mathrm{CO}$ ). The consolidated text reflected both the position in the Malayan Union and the Straits Settlements, of which Singapore was a part, contained in the case of the latter in the Companies Ordinance 1940 (SS 49 of 1940).

169 S 342, CO.

170 S 343, CO. Similar treatment was accorded to a record of evidence taken by the other court under s 356, CO.

171 S 344, CO.

172 S 345, CO. Applications could also be made for the opening of ancillary proceedings under s 353, CO. Power was also given for the appointment of a provisional ancillary liquidator under $\mathrm{s} 355, \mathrm{CO}$ in anticipation of a request being made.

173 S 346, CO.

174 S 347, CO.

175 S 349, CO. 
the company. ${ }^{176}$ The courts also enjoyed the power to compel discovery and information about the affairs of the company. ${ }^{177}$ The courts were also empowered to transmit cases between the principal and ancillary jurisdiction for the determination of a particular issue. ${ }^{178}$ Unfortunately, these reciprocal provisions did not survive the redrafting of legislation, perhaps because it was felt that the statutory jurisdiction model outlined in the previous section was adequate to deal with the phenomenon of ancillary proceedings in the case of a foreign company. Nevertheless, they are a useful example of an early type of co-operation provision, albeit limited to a bilateral model, as they only applied to relations between Malaysia and Singapore.

\section{$6 \quad$ International developments}

\subsection{UNCITRAL Model Law}

Malaysia and Singapore have not been immune to global tides of recession that have had a damaging effect on the economies of both nations. Interest has been growing in the effective management of economic problems, including whether the appropriate mechanisms exist in domestic law to deal with the impact on domestic companies of financial difficulties. An international project in which there has been some interest in the region is the UNCITRAL Model Law on Cross-Border Insolvency 1997. ${ }^{179}$ Approval was given by the General Assembly of the United Nations on 15 December 1997 in a resolution noting that the inadequate co-ordination and co-operation existing in cases of crossborder insolvency reduced the possibility of rescuing viable businesses and impedes the proper and efficient conduct of proceedings resulting in a significant disadvantage for creditors and employees. The text of the resolution goes on to recommend that member-states review their insolvency legislation and give favourable consideration to enacting the Model Law. ${ }^{180}$ The Model 
Law contains four key areas outlining the scope of the Model Law itself and rules for access by representatives of foreign insolvency proceedings, including those governing the treatment of foreign creditors. It also covers the effects of domestic recognition of foreign procedures and, most importantly, rules for cooperation and for co-ordination of simultaneous proceedings in several jurisdictions over the same debtor. The text represents essentially a compromise between different legislative traditions and is accompanied by a Guide to Enactment, which was produced in order to assist legislative draftsmen in adapting the Model Law to local conditions.

Till now, the Model Law has been adopted by a growing number of countries, ${ }^{181}$ indicating the potential interest it may have for Malaysia and Singapore. A number of other countries are known to be considering the Model Law for adoption, including Australia and Canada, while other countries in ASEAN reported to be favourable include Thailand. ${ }^{182}$ Although Malaysia has expressed an interest in the overall conclusion of the text, ${ }^{183}$ the more recent activity of the Companies Commission of Malaysia and its proposals for reform, although mentioning the interest that the issue of cross-border insolvency may have in its review of core company law, has not expressly declared that the topic is to be treated as part of the review. ${ }^{184}$ This also seems to be the position taken by the Singapore Companies Legislation and Regulatory Framework Committee, which reported in 2002, but did not recommended the adoption of the Model Law, preferring to wait to see how the impact in "major common law jurisdictions" will be felt. ${ }^{185}$ It thus remains to be seen whether a sufficient number of the nations with whom Malaysia and Singapore have strong trading links will adopt the text, thus making a stronger case for both nations to do so. Nonetheless, there are developments occurring in the regional context, dealt

181 These include the British Virgin Islands, Colombia, Eritrea, Japan, Mexico, New Zealand, Poland, Romania, Montenegro, Serbia, South Africa, the UK and the USA (see UNCITRAL http://www.un.org/ 31 Aug.

182 According to Stewart "UNCITRAL Model Law".

183 See Omar http://www.undp.org/ 31 Aug (site no longer available).

184 CCM supra $\mathrm{n} 17$ at 26.

185 Lee supra n 94 at 331, citing par 1.3 in ch 4 of the report. 
with below, that may push the agenda for the adoption of the Model Law proper or a tailored version for local consumption.

\subsection{The Asian Development Bank Initiative}

The Asian Development Bank, covering the region in which both Malaysia and Singapore are located, initiated a project in providing regional technical assistance for the updating of insolvency laws of its member states. ${ }^{186}$ This project was carried out through the law and development initiative of the bank and is intended to provide a regional forum for government officials and interested parties to discuss insolvency problems and exchange ideas on reform and best practice. A study was carried out into the relationship between corporate debt and recovery and corporate insolvency in eleven Asian economies, which reported in 1999. Part of the comparison involved identifying areas of similarity and differences and, in light of this, developing key areas for evaluation as well as a model for best practice, on which reforms might be attempted. The project was accompanied by technical aid for reform projects the participating Governments wished to carry out. In the wake of this initiative, two later reports, also commissioned by the Asian Development Bank, have formed the basis on which specific recommendations were made for dealing with cross-border insolvency issues. The first, produced in $2000,{ }^{187}$ set out good practice standards in insolvency law to be used as part of any reform strategy. Good Practice Standard number 16 states that provision should be made within the context of any reforms for cross-border insolvency, the preference being that this could be achieved through the adoption of the Model Law. A later 2005 report takes this recommendation further by providing two draft texts by which this goal could be achieved. ${ }^{188}$ The first of these takes the form of a regional treaty incorporating the features of the Model Law, while the second is in the form of a statement of some twenty agreed principles, which form part of a scheme for regional cooperation in cross-border insolvency

186 Based on material available at Insolvency Asia http://www.insolvencyasia.com/ 21 Aug.

187 ADB Office of the General Council http://www.adb.org 31 Aug.

188 ADB Blake Dawson Waldron and PwC http://www.adb.org 31 Aug. 
matters. ${ }^{189}$ Thus far, neither Malaysia nor Singapore appear to have acted on the content of these proposals and it remains to be seen whether sufficient interest will be shown by client states of the Asian Development Bank in taking these projects further.

\section{$7 \quad$ Summary}

The rise of international commerce and the ease of setting up in more than one jurisdiction now mean that many companies have little difficulty in gearing their economic expansion to a global scale. Just as expansion has brought considerations of conflicts of law and choice of law in international contracts and litigation, so too the periodic downturns in the world economy have brought considerations of private international law rules in relation to insolvencies. Insolvencies with an international dimension raise a number of important issues, including the diversity of laws which are potentially applicable to the transactions of a single company and which have important consequences at the time of insolvency. This phenomenon has induced courts to begin to cooperate with each other, realising that insolvency can have far-reaching consequences on society and economies, both local and foreign. With the number of international insolvencies likely to increase, as a function of periodic decline in the world economy, this spirit of co-operation can only be positive. The trend in many countries has been to seek to deal with insolvencies containing an international element by exercising exorbitant or ancillary jurisdiction, depending to which of the territorial or universal models of insolvency that country subscribes.

In Malaysia and Singapore, despite the incremental growth of cross-border trade and transactions, neither jurisdiction appears to have the necessary legislative tools to be able to properly exercise control over cross-border insolvencies. In Singapore, commentators state that the law does not as yet appear sufficiently comprehensive to deal with the complicated nature of cross- 
border questions arising in the course of the insolvency of foreign companies. Nevertheless, there is a growing awareness of the need to amend the law before these problems are aggravated. ${ }^{190}$ The same case could be made for Malaysia, where a great number of foreign companies operate and where the insolvency of some of these companies is a statistical possibility. In both jurisdictions, there is a strong case for legislative action to take place at an early opportunity during a periodic review of the framework for company and insolvency law. This review is particularly urgent in the case of Malaysia where companies' legislation dates from 1965 and, although the subject of occasional though minor amendments, would benefit from the wholesale revision that now appears to be the subject of the initiative by the Companies Commission of Malaysia. In light of the work that is being carried out in the region by international bodies operating in the financial sector, it seems likely that insolvency law and its cross-border aspect will at some point become a priority for law reform initiatives in both countries. This would seem especially cogent and necessary given that the framework for international insolvency has been considerable advanced by the adoption of the UNCITRAL Model Law on CrossBorder Insolvency 1997, a text of immense utility that has now been adopted by a significant number of the trading partners of both these jurisdictions. Arguably, the incorporation of its provisions within any revision that is carried out in these jurisdictions or the adoption of one of the Asian Development Bank's recommended models (regional treaty or scheme) would do much to advance the recognition of the inevitable cross-border dimension to insolvency law today. 


\section{Bibliography}

Bidin 2004 ICCLR 344

Bidin A "Insolvency and Corporate Rescues in Malaysia" 2004 (15)

International Company and Commercial Law Review 344

Blom-Cooper 1954 ICLQ 604 (part 1)

Blom-Cooper L "Bankruptcy in English Private International Law" 1954 (3) ICLQ 604 (part 2)

Blom-Cooper 1955 ICLQ 1 (part 2)

Blom-Cooper L "Bankruptcy in English Private International Law" 1955 (4) ICLQ 1

Blom-Cooper 1955 ICLQ 170 (part 3)

Blom-Cooper L "Bankruptcy in English Private International Law" 1955 (4) ICLQ 170

Collins et al (eds) Conflict of Laws 1150

Collins L et al (eds) Dicey and Morris on The Conflict of Laws (Stevens and Sons London 1987)

Cooper and Jarvis (eds) Cross-Border Insolvency

Cooper N and Jarvis R (eds) Recognition and Enforcement of Cross-Border Insolvency: A Guide to International Practice (Wiley London 1997)

Dawson 1999 Co Law 304

Dawson K "Jurisdiction to wind up a foreign company and cross-claims: Re Latreefers Inc" 1999 (20) Co Law 304

Dine 1988 Co Law 30

Dine J "Jurisdiction to wind up a foreign company" 1988 (9) Co Law 30 
Grace 1986 ICLQ 689

Grace AD "Law of Liquidations: The Recognition and Enforcement of Foreign Liquidation Orders in Canada and Australia - A Critical Comparison" 1986 (35) ICLQ 664

Graham 1989 CLP 225

Graham D "Cross-Border Insolvency" 1989 CLP 217

Graham 2001 IIR 159

Graham D "Discovering Jabez Henry: Cross-Border Insolvency Law in the $19^{\text {th }}$ century" $2001(10)$ IIR 153

Lipstein 1949 ModLR 454

Lipstein K "Jurisdiction in Bankruptcy" 1949 (12) ModLR 454

Markham Victorian Insolvency 295-296

Markham LV Victorian Insolvency (Clarendon Press Oxford 1995)

Moss 2006 Insolv Int 123

Moss G "Common Law Assistance comes of age" 2006 (19) Insolv Int 123

Nadelmann 1947 ModLR 154

Nadelmann K "Solomons v Ross and International Bankruptcy Law" 1947

(9) ModLR 154

North and Fawcett Private International Law

North P and Fawcett JJ Cheshire and North's Private International Law $12^{\text {th }}$ ed (Butterworths London 1992)

Omar 1996 MalLJ

Omar PJ "Co-operation in International Insolvencies" 1996 (2) Malayan Law Journal i 


\section{Omar 1998 MalLJ}

Omar PJ "Co-operation in International Insolvencies" 1998 (4) Malayan Law Journal cxxi

Roberts-Wray Commonwealth and Colonial Law 554-555

Roberts-Wray K Commonwealth and Colonial Law (Stevens and Sons London 1966)

\section{Smart 1996 ICLQ 177}

Smart P "Jurisdiction to Wind Up Companies Incorporated in Northern Ireland" 1996 (45) ICLQ 177

\section{Stewart "UNCITRAL Model Law"}

Stewart G "UNCITRAL Model Law and Cross-Border Insolvency" (unpublished paper delivered at conference on Legal Aspects of CrossBorder Insolvency BIICL London 14 July 1998)

Topham 1903 LQR 295

Topham A “A Defect in Our Law of International Bankruptcy" 1903 (14) LQR 295

Walters 2007 Co Law 73

Walters A "Judicial Assistance in Cross-Border Insolvency at Common Law" 2007 (28) Co Law 73

Wessels Cross-Border Insolvency Law

Wessels B Cross-Border Insolvency Law: International Instruments and Commentary (Kluwer Alphen aan den Rijn 2007)

Wood Principles of International Insolvency 250

Wood P Principles of International Insolvency (Sweet and Maxwell London 1995) 
Woon and Hicks Companies Act of Singapore

Woon W and Hicks A The Companies Act of SingapoRe An Annotation (Butterworths Asia Singapore 1994)

Woon Company Law

Woon W Company Law $2^{\text {nd }}$ ed (Sweet and Maxwell Asia Petaling Jaya 1999)

Wu Malaysian Legal System 14-16

Wu MA The Malaysian Legal System $2^{\text {nd }}$ ed (Longman Malaysia Kuala Lumpur 1999)

\section{Register of legislation}

Anglo-Siam Treaty 1909

Application of English Law Act 1993

Bankruptcy (Amendment) Act A1197 of 2003

Bankruptcy (Ireland) Act 1872

Bankruptcy Act 15 of 1995

Bankruptcy Act 1849 (UK)

Bankruptcy Act 1869 (UK)

Bankruptcy Act 1883 (UK)

Bankruptcy Act 1914

Bankruptcy Ordinance of Sarawak

Bankruptcy Ordinance of the States of Malaya

Cap 20 of the Statutes of Singapore (2000 rev ed)

Cap 43 of the Statutes of Singapore (1988 rev ed)

Cap 50 of the Statutes of Singapore (2006 rev ed)

Cap 7A of the Statutes of Singapore (1993 rev ed)

Charter of Justice 1807

Charter of Justice 1826

Civil Law (Extension) Ordinance 1951

Civil Law Act 1956

Civil Law Enactment 1937

Civil Law Ordinance 1878 
Civil Law Ordinance 1938 (rev 1951)

Companies (Consolidation) Act 1908 (UK)

Companies (Winding-Up) Act 1890 (UK)

Companies (Winding-Up) Rules 1890 (UK)

Companies (Winding-Up) Rules 1972 (Malaysia)

Companies Act 125 of 1965

Companies Act 1862 (UK)

Companies Act 1929 (UK)

Companies Act 1948 (UK)

Companies Act 1967

Companies Act 1985

Companies Act 2006

Companies Code

Companies Code 1981

Companies Enactment 1897 (rep 1917)

Companies Ordinance 1940

Company Ordinance 1950

Company Ordinance 1956

Corporations Act 1989 (retitled Corporations Law)

Corporations Act 2001

Corporations Legislation Amendment Act 1990

Criminal Procedure Code 1902

Enterprise Act 2002

European Insolvency Regulation: Council Regulation (EC) No 1346/2000 29

May 2000

Greek Decree 1949

Indian Companies Ordinance 1866

Insolvency Act 1986 (UK)

Insolvency Ordinance of Sabah

Insolvency Rules 1986 (UK)

Joint Stock Companies Act 1848 (UK)

Law of Sarawak Ordinance 1928 (rev 1949)

Malayan Union Companies Ordinance 1946

Malaysian Act 1967 
Malaysian Constitution

Penal Code 1905

Pengurusan Danaharta Nasional Berhad Act 587 of 1998

Singapore Constitution

Statute of Westminster 1931

Third Parties (Rights against Insurers) Act 1930

Uniform Companies Act 1961

United States Bankruptcy Code

\section{Register of court cases}

Amos William Dawe v Development and Commercial Bank [1981] MLJ 230

Banque des Marchands de Moscou v Kindersley [1951] 1 Ch 112

British South Africa Company v Companhia de Mocambique [1893] AC 602

Callender Sykes and Co v Colonial Secretary of Lagos [1891] AC 460

Cambridge Gas Transport Group Corp v The Official Committee of Unsecured

Creditors of Navigator Holdings PLC [2006] UKPC 26

Clunies-Ross v Totterdell (1988) 98 ALR 245

Felixstowe Dock and Railway Co v United States Lines [1988] 2 All ER 77

Galbraith v Grimshaw [1910] AC 508

Gibbs and Sons v Société Industrielle et Commerciale des Métaux (1890) 25

QBD 399

Government of India v Taylor [1955] AC 491

International Westminster Bank PLC v Okeanos Maritime Corp [1987] BCLC 450

Interpool Ltd $v$ KKL and others 102 BR 373 (1988)

Lazard Brothers and Co v Midland Bank Ltd [1933] AC 289

Lindner Fund Inc v Polly Peck International PLC 143 BR 807 (1992)

Logan v Bank of Scotland (No 2) [1906] 1 KB 141

Mareva Compania Naviera SA v International Bulkcarriers SA, The Mareva

[1975] 2 Lloyd's Rep 509

Metliss v National Bank of Greece and Athens SA [1958] AC 509

Mills v Mills (1938) 60 CLR 150 
New Hampshire Insurance Co v Rush and Tompkins Group PLC and another [1998] 2 BCLC 471

Radich v Bank of New Zealand (1993) 116 ALR 676

Re A Company (No 00359 of 1987) [1988] 1 Ch 210

Re A Company (No 007946 of 1993) [1994] 2 WLR 438

Re A Debtor (ex parte the Viscount of the Royal Court of Jersey) [1980] 3 All ER 665

$\operatorname{Re}$ A Debtor [1981] Ch 384

Re Alfred Shaw and Co (1897) QLJ 93

Re Allobrogia Steamship Corporation [1978] 3 All ER 425

Re Atlantic Isle Shipping Co Inc (1988) 6 ACLC 992

Re Australian Life and General Assurance Company [1931] VLR 317

Re Azoff-Don Commercial Bank [1954] Ch 315

Re Banco Ambrosiano Overseas Ltd Bkrtcy 25 BR 621 (1982)

Re Banque des Marchands de Moscou (Koupetschetsky) (Royal Exchange

Assurance $v$ Liquidator) [1952] 1 All ER 1269; Idem (Ouchkoff v Liquidator)

[1954] 2 All ER 746

Re Buildmat (Australia) Pty Ltd (1981) CLC 40-714

Re China Underwriters Life and General Insurance Co Ltd [1988] 1 MLJ 409

Re Commercial Bank of India (1868) LR 6 Eq 517

Re Commercial Bank of South Australia (1886) 33 Ch D 174

Re Compania Merabello San Nicholas SA [1973] 1 Ch 75

Re Eloc Electro-Optieck and Communicatie BV [1982] 1 Ch 43

Re English, Scottish and Australian Chartered Bank [1893] 3 Ch 385

Re Federal Bank of Australia (1893) 62 LJ Ch 56

Re Fogarty (1904) QWN 67

Re Gibbons (1960) Irish Jurist 60

Re Graham [1928] 4 DLR 375

Re Greenaway (1910) WN (NSW) 112

Re Griffin Securities Corporation [1999] 3 SLR 346

Re Hibernian Merchants Ltd [1957] 3 All ER 97

Re Jackson (1973) NILR 67

Re James [1977] 1 All ER 364

Re Jarvis (1895) 11 TLR 373 
Re Kailis Groote Eylandt Fisheries Pty Ltd [1977] 2 ACLR 574

Re Latreefers Inc [1999] 1 BCLC 271

Re Matheson Brothers Ltd (1884) 27 Ch D 225

Re Maundy Gregory (1934) 103 LJ Ch 267

Re Mercantile Bank of Australia [1892] 2 Ch 204

Re Nall (1899) 20 NSWR 25

Re Norfolk Shipping Line Pty Ltd (1988) 6 ACLC 990

Re Osborne [1931-32] 15 B \& CR 189

Re P MacFadyen and Co, ex parte Vizianagaram Company Limited [1908] 1 KB 675

Re Russian Bank for Foreign Trade [1933] 1 Ch 745

Re Suidair International Airways Ltd [1951] 1 Ch 165

Re Syria Ottoman Railway Company (1904) 20 TLR 217

Re Trepca Mines [1960] 3 All ER 304

Re Vocalion (Foreign) Ltd [1932] 2 Ch 196

Re Wallace Smith Group Ltd [1992] BCLC 989

Real Estate Development Co [1991] BCLC 210

Russian and English Bank v Baring Bros and Co [1936] AC 405

Schemmer and Others $v$ Property Resources Ltd and Others [1975] 1 Ch 273

Sill v Worswick (1781) $1 \mathrm{H} \mathrm{BI} 665$

Solomons $v$ Ross (1764) 1 Hy BI 131n, 126 ER 79

Spiliada Maritime Corp v Cansulex Ltd [1987] AC 480

Stocznia Gdanska SA v Latreefers Inc [2000] EWCA Civ 36 (9 February 2000)

Tharsis Ltd v La Société des Métaux (1889) 58 LJ QB 435

The Atlantic Star [1974] AC 436

Tohru Motorbayashi v Official Receiver [2000] 4 SLR 529

Tong Aik (Far East) Ltd v Eastern Minerals and Trading (1959) Ltd [1965] 2 MLJ 149

United Kingdom Tobacco (1929) Ltd v Malayan Tobacco Distributors Ltd [1933] MLJ 1

Yeap Cheah Neo v Ong Cheng Neo (1875) LR 6 PC 381 


\section{Register of Internet resources}

ADB Blake Dawson Waldron and PwC http://www.adb.org 31 Aug

Asian Development Bank: Blake Dawson Waldron and

PricewaterhouseCooper "Asian Development Bank: Promoting Regional

Cooperation in the Development of Insolvency Law Regimes" 2005 Final

Report (RETA 5975) [Found on internet] http://www.adb.org [Date of use 31

August 2007]

ADB Office of the General Council http://www.adb.org 31 Aug

Asian Development Bank: Office of the General Council "Law and Policy Reform at the Asian Development Bank" 2000 (RETA 5975) [Found on internet] http://www.adb.org [Date of use 31 August 2007]

Bte Abdullah http://www.aseanlawassociation.org/ 31 Aug

Bte Abdullah RA "Paper on Malaysian Position in the Session on Recent Developments on Insolvency Laws and Business Rehabilitation - National and Cross Border Issues" $8^{\text {th }}$ General Assembly of the Asean Law Association 29 November - 2 December 2003 Singapore [Found on internet] http://www.aseanlawassociation.org/docs/w6 malaysia.pdf [Date of use 31 August 2007]

CCM http://www.ssm.com.my/clrc/cd1.pdf 31 Aug

Companies Commission of Malaysia "Strategic Framework for the Corporate Law Reform Programme" [Found on internet] http://www.ssm.com.my/clrc/cd1.pdf [Date of use 31 August 2007]

Chang http://www.aseanlawassociation.org/ 31 Aug

Chang W "Legal Systems in ASEAN - Singapore, Chapter 1 Historical Overview" 6 [Found on internet] http://www.aseanlawassociation.org/papers/sing chp1.pdf [Date of use 31 August 2007) 
Danaharta Final Report http://www.danaharta.com.my 31 Aug

Danaharta Final Report 30 September 2005 [Found on internet]

http://www.danaharta.com.my/default.html [Date of use 31 August 2007]

Insolvency Asia http://www.insolvencyasia.com/ 21 Aug

Insolvency Asia [Found on internet] http://www.insolvencyasia.com/ [Date

of use 21 August 2007]

Lee http://www.aseanlawassociation.org/ 31 Aug

Lee EB "Paper on Singapore Position in the Session on Recent

Developments on Insolvency Laws and Business Rehabilitation - National

and Cross Border Issues" $8^{\text {th }}$ General Assembly of the Asean Law

Association 29 November - 2 December 2003 Singapore [Found on

internet] http://www.aseanlawassociation.org/docs/w6 sing.pdf [Date of use

31 August 2007]

Omar http://www.undp.org/ 31 Aug

Omar N "Statement on Agenda Item 148, Report of UNCITRAL on the

Work of its Thirtieth Session" (6 October 1997) [Found on internet]

http://www.undp.org/missions/malaysia/uncitral.htm [Date of use 31 August 2007]

Report of the Review Committee on Insolvency Law and Practice [Cmnd 8558] (1982)

UN Res No 52/158 http://www.un.org/ 31 Aug

UN Res No 52/158 [Found on internet]

http://www.un.org/ga/documents/gares52/res52158.htm [Date of use 31

August 2007]

UNCITRAL http://www.un.org/ 31 Aug

UNCITRAL "Status of Texts section" [Found on internet] http://www.un.org/

[Date of use 31 August 2007] 
UNCITRAL Model Law http://www.uncitral.org/ 31 Aug

UNCITRAL Model Law on Cross-Border Insolvency 1997 [Found on internet]

http://www.uncitral.org/uncitral/en/uncitral texts/insolvency/1997Model.html [Date of use 31 August 2007]

\section{List of abbreviations}

ADB

Asian Development Bank

ASEAN

Association of South East Asian Nations

$\mathrm{CCM}$

Companies Commission of Malaysia

ch

chapter(s)

CLP

Current Legal Problems

Co Law

Company Lawyer

ICCLR

International Company and Commercial Law Review

ICLQ International and Comparative Law Quarterly

IIR International Insolvency Review

Insolv Int

Insolvency Intelligence

Insolv L

Insolvency Lawyer

JBL

Journal of Business Law

LQR

Law Quarterly Review

MalLJ

Malayan Law Journal

ModLR

Modern Law Review

par

paragraph(s)

reg

regulation(s)

$\mathrm{S}$

section(s)

sch

schedule(s) 